\title{
Geologia
}

\section{Extensional and Colisional Magmatic Records in the Apiaí Terrane, South-Southeastern Brazil: Integration of G eochronological U-Pb Zircon Ages}

\author{
Registros Magmáticos Extensionais e Colisionais no Terreno Apiaí, Sul-Sudeste do \\ Brasil: Integração de Dados U-Pb - Zircão
}

O swaldo Siga Junior ${ }^{1}$ (osigajr@ usp.br), Miguel Angelo Stipp Basei (baseimas@ usp.br), Allen Nutman²,3 (allen.nutman@anu.edu.au), Kei Sato ${ }^{1}$ (keisato@ usp.br), lan McReath ${ }^{1}$ (ianmcr@ usp.br),

Cláudia Regina Passarelli (cr_passarelli@ hotmail.com), Dunyi Liu² (liudunyi@ bjshrimp.cn)

1Departamento de Mineralogia e G eotectônica - Instituto de Geociências - USP

R. do Lago 562, CEP 05508-900, São Paulo, SP, BR

${ }^{2}$ Beijing SHRIMP Center - Institute of G eology - Chinese Academy of Geological Sciences, Beijing, CN

${ }^{3}$ School of Earth and Environmental Sciences - University of Wollongong, Wollongong, AU

Received 12 april 2011; accepted 25 october 2011

\begin{abstract}
The aim of this work is the presentation of a synthesis of available geochronological data for the basement inliers and metavolcano-sedimentary sequences which occur in the southern part of the Apiai Terrane, south-southeastern Brazil. These data, especially those obtained during the last decade, have made substantial modifications to the tectonic scenario of south-southeastern Brazil with the recognition of the presence of extensional basins (continental rifts) with magmatism and sedimentation at the late Paleoproterozoic (1790 - $1750 \mathrm{Ma})$ and of the Mesoproterozoic (1600 - $1450 \mathrm{Ma})$. These processes started at the late Paleoproterozoic in the Betara, Perau and Apiai Mirim Nuclei, and the basins became wider during the Mesoproterozoic with the deposition of the Betara, Perau, Votuverava and Água Clara metavolcano-sedimentary sequences. A different pattern is found for the Itaicoca Sequence which occupies the northern part of the Apiaí Terrain. Here two rock associations of different ages are found. The first is a metamorphosed carbonate platform association with subalkaline, tholeiitic metabasic rocks with minimum deposition ages at the end of the Mesoproterozoic or beginning of the Neoproterozoic (Itaiacoca Sequence; 1030 - $900 \mathrm{Ma}$ ), while the second mainly contains metapsammites and metavolcanic rocks including ultrapotassic trachytes deposited during the Cryogenian-Ediacaran transition between 645 and $628 \mathrm{Ma}$ (Abapã Sequence). It is then proposed that the present scenario of the Apiaí Terrane be representative of the distinct tectono-sedimentary histories, reflecting a polycyclic evolution. In the Mesoproterozoic, stable conditions prevailed, with the deposition of the majority of the sequences (Lajeado, Água Clara, Betara, Perau, Votuverava) in a passive margin context, succeded by a Tonian extensional phase (deposition of the Itaiacoca Sequence). In the Ediacaran the region was transformed into an unstable active margin, with the predominance of magmatic arcs (Três Córregos, Cunhaporanga and Agudos Grandes) and restricted sedimentation (Abapã, Antinha and Iporanga Sequences).
\end{abstract}

Keywords: Apiaí Terrane; Records of Paleo (1790 - $1.750 \mathrm{Ma}$ ) to Mesoproterozoic (1600 - 1.450 Ma); Records of lowerupper Neoproterozoic (1030 - 900 and 645 - $630 \mathrm{Ma}$ ); Cyclic crustal evolution; Integration of geochronological data.

\section{RESUMO}

O principal objetivo deste trabalho é apresentar uma síntese dos dados geocronológicos disponíveis para as sequências metavulcano-sedimentares e núcleos de embasamento que ocorrem na porção sul do Terreno Apiaí, sul-sudeste do Brasil. Os dados obtidos, principalmente na última década, têm modificado substancialmente o cenário tectônico do sul-sudeste brasileiro, identificando a presença de bacias extensionais (rifts continentais) com magmatismo e sedimentação associada do final do Paleoproterozoico (1790 - $1750 \mathrm{Ma}$ ) e do Mesoproterozoico (1600 - $1450 \mathrm{Ma}$ ). O desenvolvimento desses processos parecem ter se iniciado no final do Paleoproterozoico (Núcleos Betara, Perau e Apiaí Mirim), evoluindo para 
bacias mais amplas durante o Mesoproterozoico com a deposição das sequências metavulcanossedimentares Betara, Perau, Votuverava e Água Clara. Padrão distinto é observado para a Sequência Itaiacoca, que ocupa a porção setentrional do Terreno Apiaí. O estudo geológico-geocronológico caracterizou a existência de dois conjuntos litológicos temporalmente distintos, o primeiro representado por uma associação plataformal metacarbonática, que inclui rochas metabásicas de natureza toleítica/subalcalina, com idades mínimas de deposição relacionadas ao final do Mesoproterozoico/início do Neoproterozoico (Sequência Itaiacoca: 1.030-900 Ma). O segundo conjunto é representado principalmente por rochas metapsamíticas com metavulcânicas associadas, incluindo traquitos ultrapotássicos, depositados na transição Criogeniano/Ediacarano (Sequência Abapã: 645-628 Ma). O presente cenário sugere histórias tectono-sedimentares distintas para o Terreno Apiaí, refletindo uma evolução policíclica. Durante o Mesoproterozoico predominaram condições relativamente estáveis com a deposição de grande parte das sequências metavulcanossedimentares (Lajeado, Água Clara, Betara, Perau, Votuverava), num contexto de margem passiva, sucedidos pela deposição da Sequência Itaiacoca, associada a regimes extensionais do Toniano. No Ediacarano prevaleceram condições instáveis, de margem ativa, caracterizadas por restrita sedimentação (Sequências Abapã, Antinha e Iporanga) e colocação dos batólitos graníticos Três Córregos, Cunhaporanga e Agudos Grandes, representantes de arcos magmáticos.

Palavras-chave: Terreno Apiaí; Registros do Paleo (1790 - 1750 Ma) e Mesoproterozoico (1600 - 1450 Ma); Registros do Neoproterozoico inferior e superior (1030 - 900 e 645 - 630 Ma); Evolução crustal policíclica; Integração de dados geocronológicos.

\section{INTRODUCTION}

To contribute to the understanding of the stratigraphy and tectonic evolution of the Apiaí Terrane (Siga Jr., 2010), south-southeastern Brazil, this work presents an integration of previous geological and geochronological studies obtained in several different parts of the Apiaí Terrane (Figure 1; Table 1). The geochronological studies were mainly based on $\mathrm{U}-\mathrm{Pb}$ analyses of zircon undertaken at the laboratories of the Geochronological Research Centre of the Geosciences Institute, São Paulo University (CPGeo-IGc-USP) using isotope dilution - thermal ion mass spectrometry (ID-TIMS) and single crystal $\mathrm{Pb}-$ $\mathrm{Pb}$ evaporation and thermal ion mass spectrometry (EVTIMS), and through international scientific collaboration programs with the laboratories of the Earth Sciences Research School, Australian National University using SHRIMP, and the SHRIMP Centre, Institute, Insitute of Geology, Chinese Academy of Geological Sciences, Beijing. Additionally, the area also presents $\mathrm{Sm}-\mathrm{Nd}$ and $\mathrm{K}-\mathrm{Ar} / \mathrm{Ar}-\mathrm{Ar}$ isotopic analyses which were carried out in the CPGeo-IGc-USP (Table 1). These studies were mainly carried out during the last ten years by the first author and research groups involved in geologic and geochronologic studies of south-southeastern Brazil. The results obtained in different compartments of the Apiaí Terrane have already been presented at scientific meetings, and a few have been published in specialized journals.

Discussions concerning the stratigraphy, timing of formation and development of the Apiaí Terrane (constrained to the Mesoproterozoic, Meso-Neoproterozoic or even to the Neoproterozoic) and its tectonic setting (continental rift, backarc basin, forearc basin) are frequent among the authors (Hasui, Carneiro, Coimbra, 1975; Hasui,
Cremonini, Born, 1984; Soares, Stevanato, Camargo, 1987; Fiori, 1992; Campanha and Sadowski, 1999; Reis Neto, 1994; Soares, Fiori, Rostirolla, 1998; Siga Jr. et al., 2009, 2011a, 2011b).

Superimposed deformation events, extensive shear zones (including thrusting and transcurrent faulting), juxtaposition of sequences, lack of exposure and preservation, and intrusion of granite make the stratigraphic successions of the Apiaí Terrane a rather difficult task. Thus, detailed geochronological studies need to be integrated with the geology to reconstruct their evolution. Based on available radiometric data and geological studies, a chronostratigraphic scenario can be presented for the Apiaí Terrane. It is then proposed that the present scenario be representative of the distinct tectono-sedimentary histories, reflecting a polycyclic evolution. The term terrane is here used in the sense of Howell (1989a, 1989b).

\section{GEOLOGICAL SETTING}

The bibliography on the Precambrian sequence of eastern Paraná and southeastern São Paulo is quite extensive, including more than a hundred publications and reports. The earlier works were dedicated to geological reconnaissance, and separated the Crystalline Basement Complex from the metasedimentary and metavolcanosedimentary sequences of the Apiaí Terrane. The difficulties in establishing stratigraphic columns and tectonic relationships for the metavolcanosedimentary terrains are shown by the numerous different proposals, as synthesized by Fassbinder (1996).

Previous studies show that in the southern portion of the Apiaí Terrane, major tectonic compartments were juxtaposed by extensive shearing, including thrust and transcurrent faults (e.g., Fiori, 1990, 1992; Campanha, 1991; 

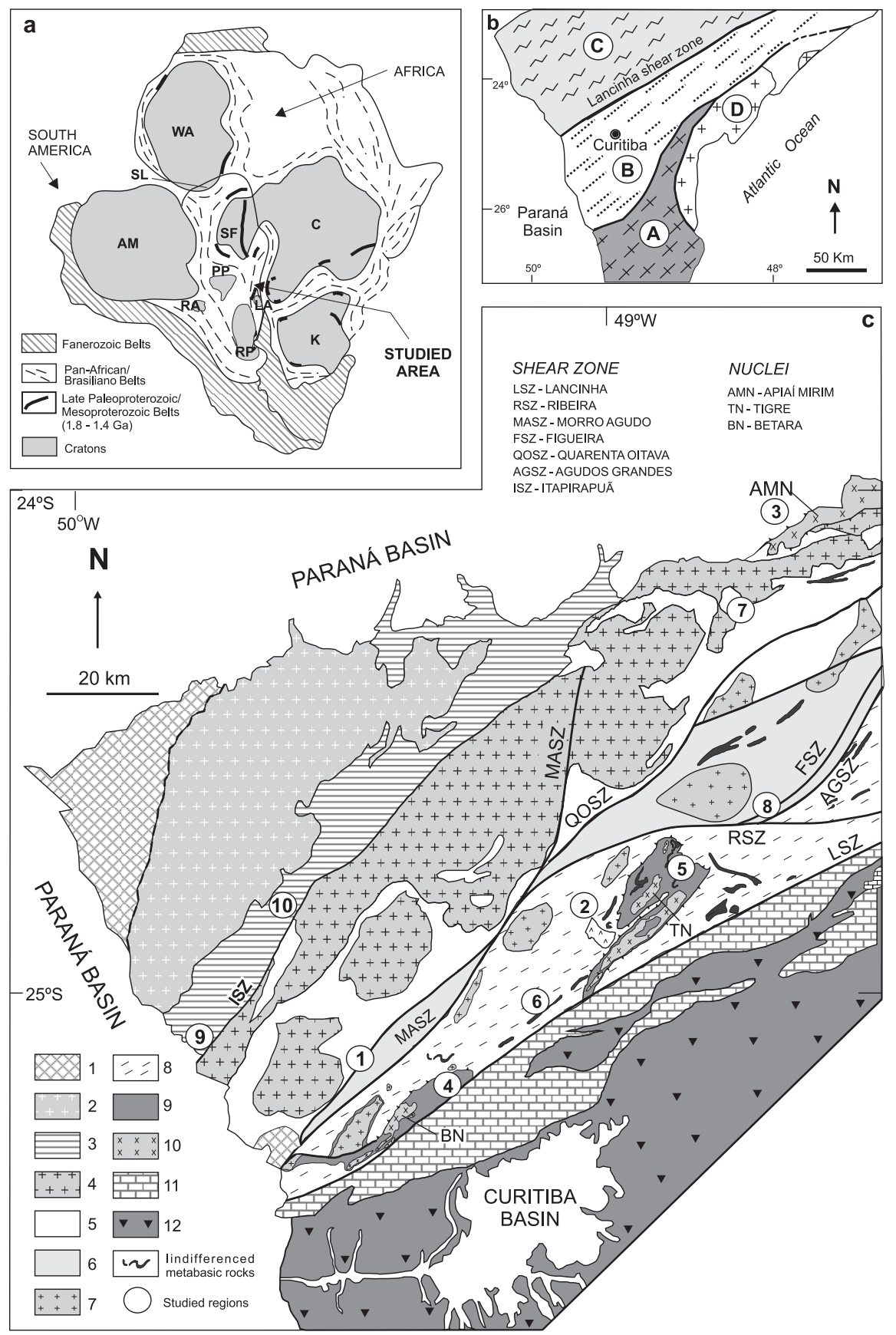

Figure 1. a. Paleogeographic Reconstruction - Western Gondwana (Cratons: AM = Amazonas, SF = São Francisco, $\mathrm{LA}=$ Luís Alves, RP = Rio de La Plata, WA = West Africa, C = Congo, KA = Kalahari; suggested by Unrug, 1997), b. Tectonic Compartments of South-Southeastern Brazil (Basei et al., 2008; Heilbron et al., 2008): A. Luís Alves Microplate, B. Atuba Complex, C. Apiaí Terrane, D. Paranaguá Batholith, c. Geological and tectonic sketchmap of the Apiaí Terrane - eastern Paraná/southeastern São Paulo (Siga Jr. et al., 2011a, 2011b): 1. Castro/Camarinha Basins [550 - 540 Ma], 2. Cunhaporanga Granitic Batholith [630 - $600 \mathrm{Ma}$ ], 3. Itaiacoca Belt [Itaiacoca Sequence: 1000 - 900 Ma and Abapã Sequence: 650 - $630 \mathrm{Ma}$ ], 4. Três Córregos Granitic Batholith [630 - $600 \mathrm{Ma}$ ], 5. Água Clara Sequence [1600 - 1470 $\mathrm{Ma}$ ], 6. Lajeado/Antinha Sequences and Iporanga Sequence [600 Ma], 7. syn- to post-collisional granitoids [580 - 560 $\mathrm{Ma}$ ], 8. Votuverava Sequence [1500 - $1450 \mathrm{Ma}$ ], 9. Perau and Betara Sequences [1500 - 1450 Ma], 10. Tigre, Betara and Apiaí M irim N uclei proto- to mylonitic alkaline [1750 Ma] and calc-alkaline [2200 Ma] granitoids, 11. Capiru/Turvo Cajati Sequences, 12. Atuba Complex [formation ages: 2100 - $2000 \mathrm{Ma}$; migmatization ages: 620 - 600 Ma]. 
Table 1. Summary of geochronological data from Metavolcanosedimentar Sequences of Southern Ribeira Belt. myl = mylonitic, amph = amphibole, mus $=$ muscovite, det $=$ detritic, FF $=$ fine fractions, $\mathrm{U}-\mathrm{Pb}$ (in zircon), inh $=$ inheritance. $(1)=$ studied regions, in Figure 1.

\begin{tabular}{|c|c|c|c|c|c|c|c|c|}
\hline & Domain & Rock type & Sample & Locatior & n(UTM) & Method & Age (Ma) & Reference \\
\hline \multirow{15}{*}{ 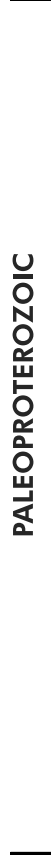 } & \multirow{7}{*}{ Betara Nuclei (1) } & $\begin{array}{c}\text { granodiorite } \\
\text { (protomylonitic) }\end{array}$ & LTB-13 & 654247 & 7200537 & $\mathrm{U}-\mathrm{Pb}$ (EV - TIMS) & $\begin{array}{c}2200 \text { (inh. } \sim 2.800 \text { ) } \\
2766 \pm 85 \\
2209 \pm 44\end{array}$ & Ribeiro (2006) \\
\hline & & & CER-08 & 648080 & 7197563 & & $1750 \pm 2$ & Cury et al. (2002) \\
\hline & & syenogranite & GKM-50 & 653809 & 7202851 & U-Pb (TIMS) & $1744 \pm 0,7$ & \multirow{3}{*}{ Kaulfuss (2001) } \\
\hline & & (mylonitic) & GKM-50.B & 653809 & 7202851 & & $1733 \pm 5$ & \\
\hline & & & GKM-50 & 653809 & 7202851 & $\mathrm{U}-\mathrm{Pb}$ (EV - TIMS) & $1800 \pm 60$ & \\
\hline & & metabasic & LBT-12 & 655800 & 7204219 & U-Pb (TIMS) & $1790 \pm 22$ & Ribeiro (2006) \\
\hline & & $\begin{array}{c}\text { syenogranite } \\
\text { myl. }\end{array}$ & GKM-50 & 653809 & 7202851 & Sm-Nd (TDM) & 2840 & \multirow{8}{*}{ Kaulfuss (2001) } \\
\hline & \multirow{7}{*}{ Tigre Nuclei (2) } & & & & & U-Pb (TIMS) & $2199 \pm 5$ & \\
\hline & & & & & & K-Ar (amph.) & $618 \pm 36$ & \\
\hline & & $\begin{array}{c}\text { qłz- } \\
\text { monzodiorite }\end{array}$ & GKM-15 & 701020 & 7246010 & Ar-Ar (amph.) & $598 \pm 1,2$ & \\
\hline & & (mylonitic) & ש & 901020 & 1240010 & K-Ar (bio) & $557 \pm 10$ & \\
\hline & & & & & & Ar-Ar (bio) & $555 \pm 1$ & \\
\hline & & & & & & Sm-Nd (TDM) & 2910 & \\
\hline & & $\begin{array}{c}\text { syenogranite } \\
\text { myl. }\end{array}$ & GKM-35 & 702100 & 7242520 & U-Pb (TIMS) & $1772 \pm 10$ & \\
\hline & $\begin{array}{l}\text { Apiaí Mirim } \\
\text { Nuclei (3) }\end{array}$ & $\begin{array}{c}\text { syenogranite } \\
\text { myl. }\end{array}$ & HP-188 & 733401 & 7490100 & U-Pb (TIMS) & $1752 \pm 9$ & $\begin{array}{c}\text { Prazeres Filho } \\
(2005)\end{array}$ \\
\hline \multirow{19}{*}{ 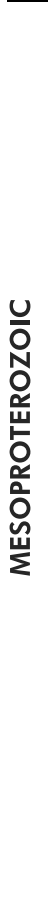 } & \multirow{7}{*}{$\begin{array}{c}\text { Betara } \\
\text { Sequence (4) }\end{array}$} & \multirow{2}{*}{ metabasic } & LBT-7A & 663275 & 7211746 & \multirow{2}{*}{$\mathrm{U}-\mathrm{Pb}$ (TIMS) } & $1489 \pm 11$ & \multirow{2}{*}{ Ribeiro (2006) } \\
\hline & & & LBT-9 & 663094 & 7211777 & & $1475 \pm 10$ & \\
\hline & & guartzite & GKM-57 & 656889 & 7205480 & K-Ar (musc) & $604 \pm 11$ & Kaulfuss (2001) \\
\hline & & quartame & 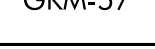 & 050007 & 1203400 & $\operatorname{Ar}-\operatorname{Ar}(\mathrm{musc})$ & $614 \pm 2$ & RAUIIUSS (2001) \\
\hline & & \multirow{3}{*}{ metabasic } & LTB-7B & 663275 & 7211746 & \multirow{3}{*}{ Sm - Nd (TDM) } & 1361 & \multirow{3}{*}{ Ribeiro (2006) } \\
\hline & & & LTB-9A & 663094 & & & 2226 & \\
\hline & & & LTB-9B & 003094 & $1211 / 11$ & & 1450 & \\
\hline & $\begin{array}{c}\text { Perau Sequence } \\
\text { (5) } \\
\end{array}$ & metabasic & GKM-41 & 705579 & 7252647 & U-Pb (SHRIMP) & $1484 \pm 16$ & Kaulfuss (2001) \\
\hline & \multirow{11}{*}{$\begin{array}{l}\text { Votuverava } \\
\text { Sequence (6) }\end{array}$} & \multirow{3}{*}{ qtz - schist } & $\mathrm{HCM}-3$ & 690210 & 7234300 & U -Pb (TIMS) det. & $2670-1940-1760$ & $\begin{array}{c}\text { Siga Jr. et al. } \\
(2011 \mathrm{~b})\end{array}$ \\
\hline & & & 32970 & 644976 & 7203750 & U-Pb (SHRIMP) & $1750 ; 2200-1900$ & \multirow{2}{*}{$\begin{array}{l}\text { Basei et al. } \\
\quad(2008)\end{array}$} \\
\hline & & & & & 1203150 & det. & $2400 ; 3200-2800$ & \\
\hline & & & $\mathrm{HCM}-01$ & 690100 & 7235010 & \multirow{2}{*}{ U -Pb (TIMS) } & $1451 \pm 39$ & \multirow{8}{*}{$\begin{array}{l}\text { Siga Jr. et al. } \\
\qquad(2011 \mathrm{~b})\end{array}$} \\
\hline & & & $\mathrm{HCM}-16$ & 695910 & 7241300 & & $1479 \pm 12$ & \\
\hline & & metabasic & HCM-16 & 695910 & 7241300 & \multirow{6}{*}{ Sm - Nd (TDM) } & 2074 & \\
\hline & & & HCM-17 & 695800 & 7240890 & & 1446 & \\
\hline & & & $\mathrm{HCM}-18$ & 698500 & 7249900 & & 1387 & \\
\hline & & \multirow{3}{*}{ phyllite } & $\mathrm{HCM}-02$ & 680800 & 7235800 & & 2294 & \\
\hline & & & HCM-08 & 689110 & 7232000 & & 2415 & \\
\hline & & & HCM-19A & 702499 & 7254510 & & 2229 & \\
\hline
\end{tabular}


Table 1. (continued)

\begin{tabular}{|c|c|c|c|c|c|c|c|c|}
\hline & Domain & Rock type & Sample & Location & n(UTM) & Method & Age (Ma) & Reference \\
\hline \multirow{10}{*}{ 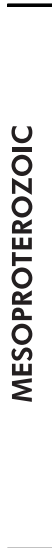 } & \multirow{10}{*}{$\begin{array}{c}\text { Água Clara } \\
\text { Sequence (7) }\end{array}$} & \multirow{8}{*}{ metabasic } & & & & $\mathrm{U}-\mathrm{Pb}$ (TIMS) & $1561 \pm 18$ & \multirow{10}{*}{$\begin{array}{c}\text { Weber et al. } \\
\text { (2003) }\end{array}$} \\
\hline & & & WWD-03 & 715954 & 7312713 & $\mathrm{U}-\mathrm{Pb}$ (SHRIMP) & $1593 \pm 70 ; 586 \pm 24$ & \\
\hline & & & & & & $\mathrm{U}-\mathrm{Pb}$ (EV-TIMS) & $1461 \pm 51$ & \\
\hline & & & WWD-32 & 721900 & 7315880 & \multirow{3}{*}{$\mathrm{U}-\mathrm{Pb}$ (TIMS) } & $1484 \pm 76 ; 601 \pm 83$ & \\
\hline & & & WWD-33 & 722400 & 7315487 & & $1485 \pm 68 ; 579 \pm 89$ & \\
\hline & & & WWD-7B & 721804 & 7316066 & & $1475 \pm 7$ & \\
\hline & & & WWD-33 & 722400 & 7315487 & Ar - Ar (amph.) & $604 \pm 8$ & \\
\hline & & & WWD-62b & 659316 & 7242120 & $\operatorname{Ar}-\operatorname{Ar}(\mathrm{musc})$ & $596 \pm 4$ & \\
\hline & & \multirow{2}{*}{ (meta) marls } & WWD-46 & 718489 & 7308800 & \multirow{2}{*}{$\mathrm{Sm}-\mathrm{Nd}$ (TDM) } & $1700-2200$ & \\
\hline & & & WWD-53B & 717875 & 7301062 & & 1780 & \\
\hline \multirow{17}{*}{ 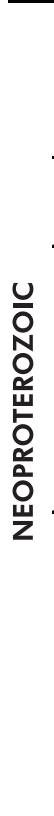 } & \multirow{2}{*}{$\begin{array}{c}\text { Lajeado/Antinha } \\
\text { Sequences (8) }\end{array}$} & (meta) psamite & |P-061 & \multicolumn{2}{|c|}{ W Iporanga } & U-Pb (SHRIMP) & $1400-2200$ & $\begin{array}{c}\text { Campanha et al. } \\
(2008 \mathrm{~b})\end{array}$ \\
\hline & & (meta) marls & 34537 & 634677 & 7201947 & det. & $\sim 2000 ; \sim 600$ & $\begin{array}{c}\text { Basei et al. } \\
(2008)\end{array}$ \\
\hline & \multirow{2}{*}{$\begin{array}{c}\text { Iporanga } \\
\text { Sequence (8) }\end{array}$} & metavolcanic & IP-808 & Iporo & anga & \multirow{2}{*}{ U-Pb (SHRIMP) } & $573 \pm 34$ & \multirow{2}{*}{$\begin{array}{c}\text { Campanha et al. } \\
(2008 b)\end{array}$} \\
\hline & & granitic clasts & F-203 A & South of I & Iporanga & & $593 \pm 15$ & \\
\hline & \multirow{6}{*}{$\begin{array}{c}\text { Itaiacoca } \\
\text { Sequence (9) }\end{array}$} & \multirow{6}{*}{ metabasic } & & & & $\mathrm{U}-\mathrm{Pb}$ (TIMS) & $934 \pm 36$ & \multirow{5}{*}{$\begin{array}{l}\text { Siga Jr. et al. } \\
\qquad(2009)\end{array}$} \\
\hline & & & HII-I4 & 610613 & 1221364 & U-Pb (SHRIMP) & $1100-900$ & \\
\hline & & & FIT-15 & 610566 & 7220771 & \multirow{2}{*}{ U - Pb (TIMS) } & $996 \pm 51$ & \\
\hline & & & & & & & $908 \pm 12$ & \\
\hline & & & FIT-17 & 620666 & 7229617 & $\mathrm{U}-\mathrm{Pb}$ (EV - TIMS) & $\sim 930$ & \\
\hline & & & & & & $\mathrm{Sm}-\mathrm{Nd}$ (TDM) & $2100-2000$ & Reis Neto (1994) \\
\hline & \multirow{7}{*}{$\begin{array}{c}\text { Abapã } \\
\text { Sequence (10) }\end{array}$} & (meta) arkose & 32928 & 619250 & 7241755 & U-Pb(SHRIMP)det. & $2200-1900$ & Basei et al. \\
\hline & & \multirow{6}{*}{ metavolcanic } & 07-B & 632316 & 7250246 & & $645 \pm 30$ & $(2008)$ \\
\hline & & & 07-A & 632316 & 7250246 & U - Pb (SHRIMP) & $641 \pm 11$ & \multirow{4}{*}{$\begin{array}{l}\text { Siga Jr. et al. } \\
\qquad(2009)\end{array}$} \\
\hline & & & $A B-1$ & 632310 & 7250175 & & $628 \pm 18$ & \\
\hline & & & HOT-2 & 621599 & 7238213 & $\mathrm{U}-\mathrm{Pb}$ (TIMS) & $636 \pm 30$ & \\
\hline & & & НОТ-2 & 621599 & 7238213 & $\mathrm{~K}-\operatorname{Ar}(\mathrm{FF})$ & $628-610$ & \\
\hline & & & HOT-2 & 621599 & 7238213 & $\mathrm{Sm}-\mathrm{Nd}$ (TDM) & $2800-2600$ & Reis Neto (1994) \\
\hline
\end{tabular}

Campanha et al., 1986; Campanha and Sadowski, 1999; Siga Jr. et al., 2008a). The dynamics of this deformational context is still uncertain.

Figure 1c shows the distribution of the Apiaí Terrane (Siga Jr. et al., 2011a, 2011b) of south-southeastern Brazil. Emphasis is given to the internal Apiaí Terrane segmentation pointing out the tectonic contacts between the several compartments.

Supracrustal rocks in low to medium metamorphic grade predominate in these compartments. The rocks include quartzite, phyllite, schist, calc-silicate rocks, marbles and metamarls, as well as basic, intermediate and acid meta-igneous rocks. The basement to these sequences is exposed in the small Betara and Tigre Nuclei which are composed mainly of Archean and Paleoproterozoic metaigneous rocks (Kaulfuss, 2001; Cury et al., 2002; Prazeres Filho, 2005; Figure 1c).

In recent years, geochronologic studies has intensified, significantly contributing to the understanding of the stratigraphy of these terranes (e.g., Tassinarietal., 1990; Reis Neto, 1994; Daitx, 1996; Maniesi and Oliveira, 1997; Basei et al., 1992, 2003, 2008; Siga Jr. et al., 1995, 2008a, 2008b, 
2009, 2011 a, 2011b; Sato and Siga Jr., 2001; Sato et al., 2003; Cury et al., 2002; Prazeres Filho et al., 2003a, 2003b, 2003c; Salazar et al., 2004; Prazeres Filho, 2005; Campanha et al., 2004, 2008a, 2009; Ribeiro, 2006; Weber et al., 2003; Oliveira et al., 2008). The presence of concordant metersized bodies of metabasic rocks in the metasedimentary rocks was fundamental to the geochronologic study of these sequences. These rocks are important stratigraphic and tectonic markers. Field relationships indicate that the igneous rocks were emplaced within the sedimentary rocks as sills and dykes. Geochemical data for metabasic rocks associated with the Betara, Perau, Votuverava and Água Clara metavolcanosedimentary sequences show clear indications of the presence of tholeiitic basalts, gabbros and cumulates. The geochemical signatures have many similarities with modern MORBs (Frascá et al., 1990; Daitx, 1996; Maniesi and Oliveira, 1998; Basei et al., 2008; Siga Jr. et al., 2011a) which suggests that the tectonic environments were extensional.

The late Paleoproterozoic (Statherian) magmatic events are registered by the granitoids and metabasic rocks in the Apiaí-Mirim, Betara and Tigre basement nuclei. The basement inliers have tectonic contacts with the overlaying metavolcanosedimentary sequences (Betara, Perau, Votuverava, Água Clara and Lajeado; Figure 1) whose minimum sedimentation ages are Mesoproterozoic (Calymmian). It is quite possible that the Mesoproterozoic extentional events that caused the opening of large sedimentary basins in southern-southeastern Brazil are underestimated. Early Neoproterozoic age (Tonian) has been obtained in the Itaiacoca metavolcanosedimentary sequence and late Neoproterozoic ages (CryogenianEdiacaran transition) in the Abapã and Iporanga sequences (Figure 1c). The 630 - 600 Ma Três Córregos and Cunhaporanga granite batholiths are believed to form part of magmatic arcs (Prazeres Filho et al., 2003a, 2003b; Prazeres Filho, 2005). 580 - 560 Ma late to post-tectonic granites intrude the metavolcanosedimentary sequences (Prazeres Filho, 2000; Cury et al., 2002; Figure 1c). The Lancinha Shear Zone would represent the surface trace of an important suture that separates the Apiaí Terrane from the terranes situated to the south of it (gneiss-migmatite rocks of the Atuba Complex; Siga Jr. et al., 1995; Figures 1b, 1c). Despite the difficulties to achieve a reasonable explanation for the entire tectonic evolution of Apiaí Terrane, tectonic models involving a Meso and Neoproterozoic polycyclic evolution are the best to explain most of the available data.

This paper starts with the presentation of the Paleoproterozoic basement inliers data and end with the discussion of the Neoproterozoic sucessions, after have presented the characterization of the important Mesoproterozoic units.

\section{PALEOPROTEROZOIC TERRANES}

The Paleoproterozoic outcrops are mainly represented by granitic-gneissic rocks, which occur as elongated nuclei (Betara, Tigre and Apiaí Mirim Nucleus) within the metavolcanosedimentary sequences of the Apiaí Terrane and are limited by shear zones (Figure 1c).

\section{The Betara Nucleus}

The Betara Nucleus is considered by most authors to represent basement, and is composed almost exclusively of deformed granodiorite and syenogranite (Kaulfuss, 2001; Cury et al., 2002) which were affected by ductile to ductile-brittle shearing which produced the protomylonitic, mylonitic and ultramylonitic structures. The deformed granitoids are found in the centre-southern part of the studied area next to the Lancinha shear zone (Figure 1c).

The mylonitic biotite granodioritic rocks occur just north of the Lancinha shear zone, which constitutes the tectonic contact with the Atuba Complex (Siga Jr. et al., 1995 ) to the south. They are light grey to reddish grey with centimetric feldspar porphyroclasts, which are usually stretched and rotated. The fine- to medium-grained matrix is constituted of quartz, feldspar, biotite, sericite and chlorite. In general, the feldspars are intensely fractured and micro-faulted, exhibiting sigmoidal forms and dominotype structures indicative of dextral movement, as found in the Lancinha Shear Zone.

The mylonitic biotite syenogranitic rocks occupy the central-southern portion of the studied area. They have tectonic contacts with the granodioritic rocks and with the metavolcanosedimentary rocks of the Betara Sequence. In general, these rocks are reddish grey and composed of potassic feldspar, quartz, plagioclase, biotite, sericite and chlorite. Porphyroclasts of alkali feldspar with dimensions between 5 and $7 \mathrm{~mm}$ are stretched. The petrographic and geochemical studies carried out by Kaulfuss (2001) indicate an affinity with (anorogenic) A-type granites, which suggests an extensional environment. Fine-grained metabasic rocks are found in association with syenogranite with field relationships with suggest that magma mixing or mingling may have occurred.

\section{Geochronology}

Isotopic records from the Archean (U-Pb/ID-TIMS, zircon: 2600 Ma) and Paleoproterozoic (U-Pb/ID-TIMS, zircon: 2200 Ma) were identified only in the granodioritic rocks of Betara nucleus (Kaulfuss, 2001; Cury et al., 2002; Ribeiro, 2006). EV-TIMS zircon analysis of grains with rounded double terminations yielded a ${ }^{207} \mathrm{~Pb} /{ }^{206} \mathrm{~Pb}$ plateau 
age of $2766 \pm 85 \mathrm{Ma}$. Two well-formed prismatic grains yielded ${ }^{207} \mathrm{~Pb} /{ }^{206} \mathrm{~Pb}$ plateaux ages of $2209 \pm 44 \mathrm{Ma}$ and 2187 $\pm 39 \mathrm{Ma}$, in agreement with interpretation of the TIMS data. Kaulfuss (2001) and Siga Jr. et al. (2008a) suggested that these rocks were formed in the Orosirian $(\sim 2200 \mathrm{Ma})$ with Neoarchean inheritance ( $2800 \mathrm{Ma})$. Sm-Nd (Tdm, whole rock) model ages obtained by Kaulfuss (2001) are 3100 $3000 \mathrm{Ma}$, indicating a large involvement of Archaean crust in the production of these Palaeoproterozoic granitoids.

The mylonitic syenogranitic rocks have translucent prismatic zircons with abundant inclusions. The zircon morphology varies from elongated to diamond-shaped crystals, and show igneous oscillatory zoning. ID-TIMS analyses of different zircon fractions form a well-aligned discordant array with an upper intercept with the Concordia at $1750 \pm 2 \mathrm{Ma}$ (Figure 2a; CER-08; Cury et al., 2002). From the central portion of the Betara Nucleus ID-TIMS analysis of zircon fractions yielded well-aligned points that cluster close an upper intercept at $1744 \pm 1 \mathrm{Ma}$ (Figure 2b; GKM50; Cury et al., 2002). A mylonitic syenogranite enriched in biotite and amphibole yielded a similar ID-TIMS zircon age of $1733 \pm 5$ Ma (Figure 2c; GKM-50B; Cury et al., 2002). An integrated Concordia diagram using the IDTIMS zircon analyses of syenogranitic rocks (Figure 2d; CER-08, GKM-50 and GKM-50B) give an age of 1748 $\pm 6 \mathrm{Ma}$, which is considered as the timing of granitoid production by high heat flow and influx of mantle- derived magmas leading to the melting of older crust during the Statherian extensional event (Siga Jr. et al., 2008a, 2008b).

Additionally, zircon crystals of the syenogranite GKM50 were analyzed by means of the EV-TIMS technique. Cathodoluminesence imaging of zircons shows that they are simple igneous oscillatory zoned crystals, devoid of inherited cores. EV-TIMS analysis of these zircons yielded $\mathrm{a}^{206} \mathrm{~Pb} /{ }^{207} \mathrm{~Pb}$ plateau age of $1800 \pm 60 \mathrm{Ma}$ (Kaulfuss, 2001; GKM-50) which, within its large error, agrees with the IDTIMS results.

In order to better understand the evolution of this sector, zircon $\mathrm{U}-\mathrm{Pb}$ ages were obtained for a metabasic rock associated with the mylonitic syenogranite. Ten crystal fractions were separated according to their habits: short prisms, bi-terminated crystals with inclusions but few fractures, fragments of fractured prisms, long bi-terminated fractured prisms with inclusions and xenomorphic crystals. The compositions of the long bi-terminated prism and fragment fractions are discordant, but those of the remaining eight fractions are concordant or almost concordant (Figures 2e, 2f; Siga Jr. et al., 2011a). The Discordia alignment defines an upper intercept at $1790 \pm 22 \mathrm{Ma}$ which represent the crystallization age of the basic rock. This indicates that the basic rocks have an age very close to that of the syenogranites, confirming the presence of bimodal Statherian magmatism.
Mylonitic syenogranite has a $\varepsilon_{\mathrm{Nd}}$ of -8.0 (GKM-50; calculated for $\mathrm{T}=1750 \mathrm{Ma}$ ) and $\mathrm{a} \mathrm{T}_{\mathrm{DM}}$ model age of $2840 \mathrm{Ma}$, suggest remelting of Archean crust during the formation of these rocks.

\section{The Tigre Nucleus}

The granitic-gneissic rocks belonging to the Tigre Nucleus occur in three main domains in the southern part of the Apiaí Terrane(Figure 1c). They constituteapproximately ellipsoidal-shaped bodies orientated NE-SW, in tectonic contact with the Perau metavolcanosedimentary sequences.

In the central and northern domains of the Tigre Nucleus, deformed quartz-monzonitic to quartz-monzodioritic rocks predominate. They are composed of epidotized plagioclase, potassicfeldspar(recrystallizedattherims), biotite, amphibole (hornblende and actinolite) and quartz. In the protomylonitic varieties, the feldspar porphyroclasts (K-feldspar) reach up to $2 \mathrm{~cm}$ in size. The matrix is composed predominantly of feldspar (plagioclase and K-feldspar), biotite, amphibole and quartz, which show strong stretching with quartz ribbons. The mylonitic rocks contain fewer feldspar porphyroclasts, which may reach $4 \mathrm{~mm}$ in size, in a quartz-feldspatic matrix with intercalated mafic films and intense mineral stretching.

In the southern domain (Figure 1c) syenogranites predominate, transformed into protomylonitic, mylonitic and ultramylonitic rocks. They are composed of K-feldspar, quartz (ribbons), plagioclase and biotite. In the protomylonitic varieties the $\mathrm{K}$-feldspar occurs as $2 \mathrm{~cm}-3 \mathrm{~cm}$ porphyroclasts within a fine- to mediumgrained matrix. The feldspar porphyroclasts present brittle to brittle-ductile behavior, with intense intracrystal fracturing, microfractures and "domino-type" structures (Figure 3a). Centimeter- to decimeter-sized mylonitic/ ultramylonitic belts (deformation corridors) occur within the protomylonitic granitoids (Figure 3b). The foliation is characterized by the development of S-C surfaces, with millimeter-sized intercalations of quartz-feldspatic and mafic layers. The ultramylonites are restricted to decimeter to meter wide shear zones.

\section{Geochronology}

Zircons from the deformed quartz-monzodioritic rocks (northern portion of the Tigre Nucleus) are predominantly oval, brownish, and rich in inclusions and fractures. IDTIMS U-Pb data for four zircon fractions are well aligned and are close to an upper concordia intercept, defining an age of $2199 \pm 5 \mathrm{Ma}$. This is interpreted to be the time of igneous crystallization of the quartz-monzodiorites in the Rhyacian (Figure 3c). These granitoids yielded $\mathrm{Nd}$ $\mathrm{T}_{\mathrm{DM}}$ model ages of $\sim 2910 \mathrm{Ma}$, indicating, as in the Betara 

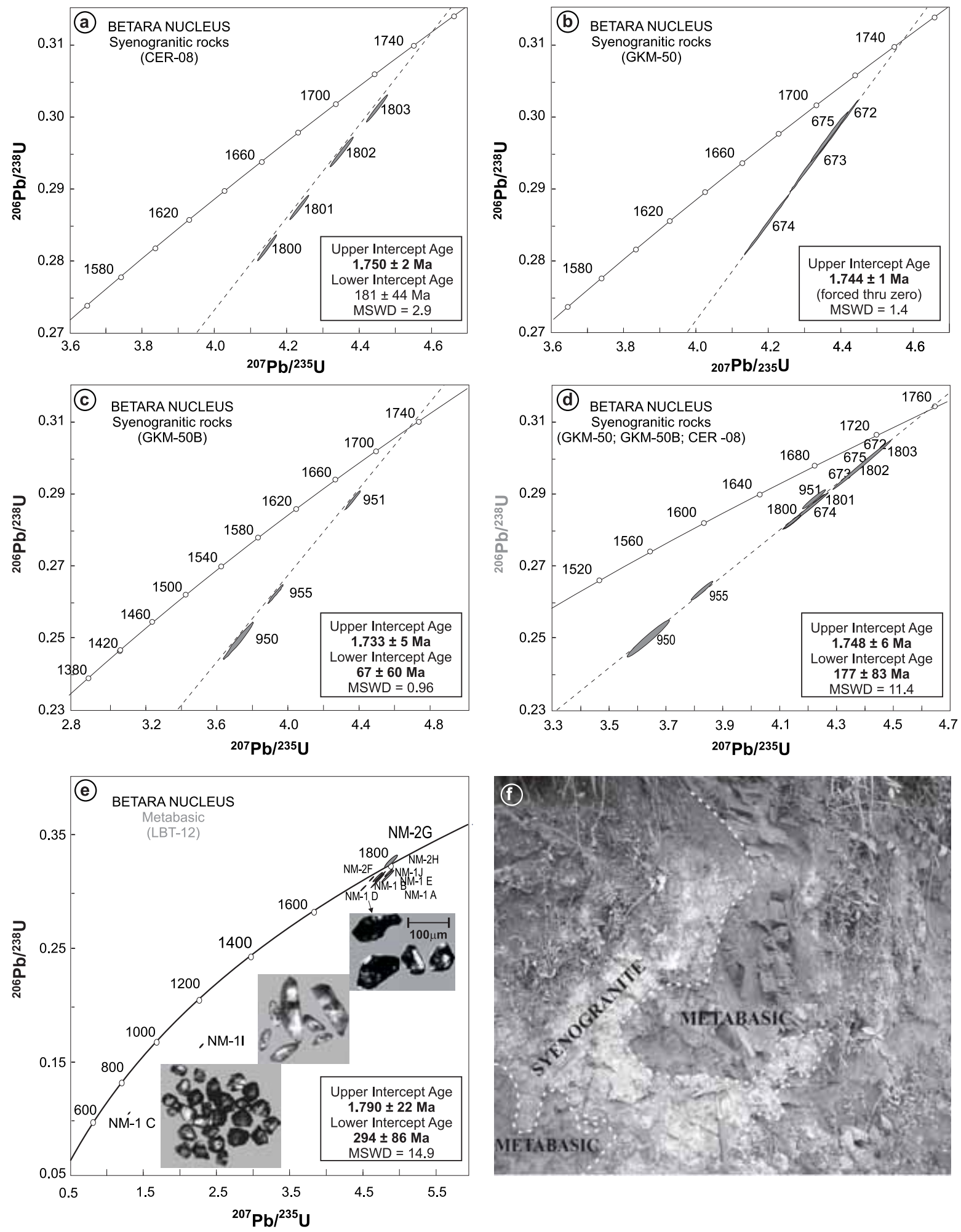

Figure 2. Zircon U-Pb analyses (ID-TIMS) for the Betara N ucleus mylonitic syenogranites: a. CER-08, b. GKM-50, c. GKM50B, d. integrated (CER-08; G KM-50 and G KM-50B; Cury et al., 2002), e. metabasic rock (LBT-12; Siga Jr. et al., 2011a), f. mylonitic syenogranite associated with metabasic rocks suggesting possible mixing or mingling between the two magmas. Zircons are $150-80 \mu \mathrm{m}$ long in the photomicrographs. 

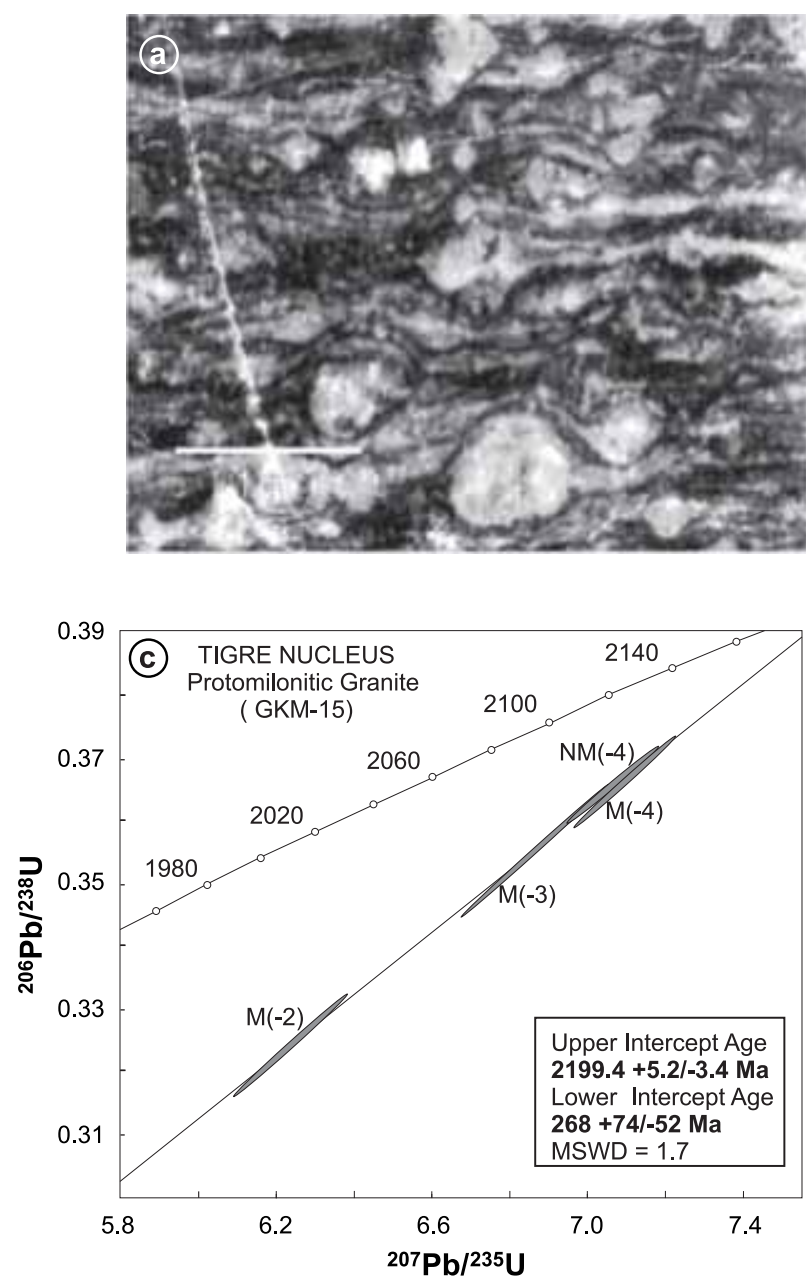
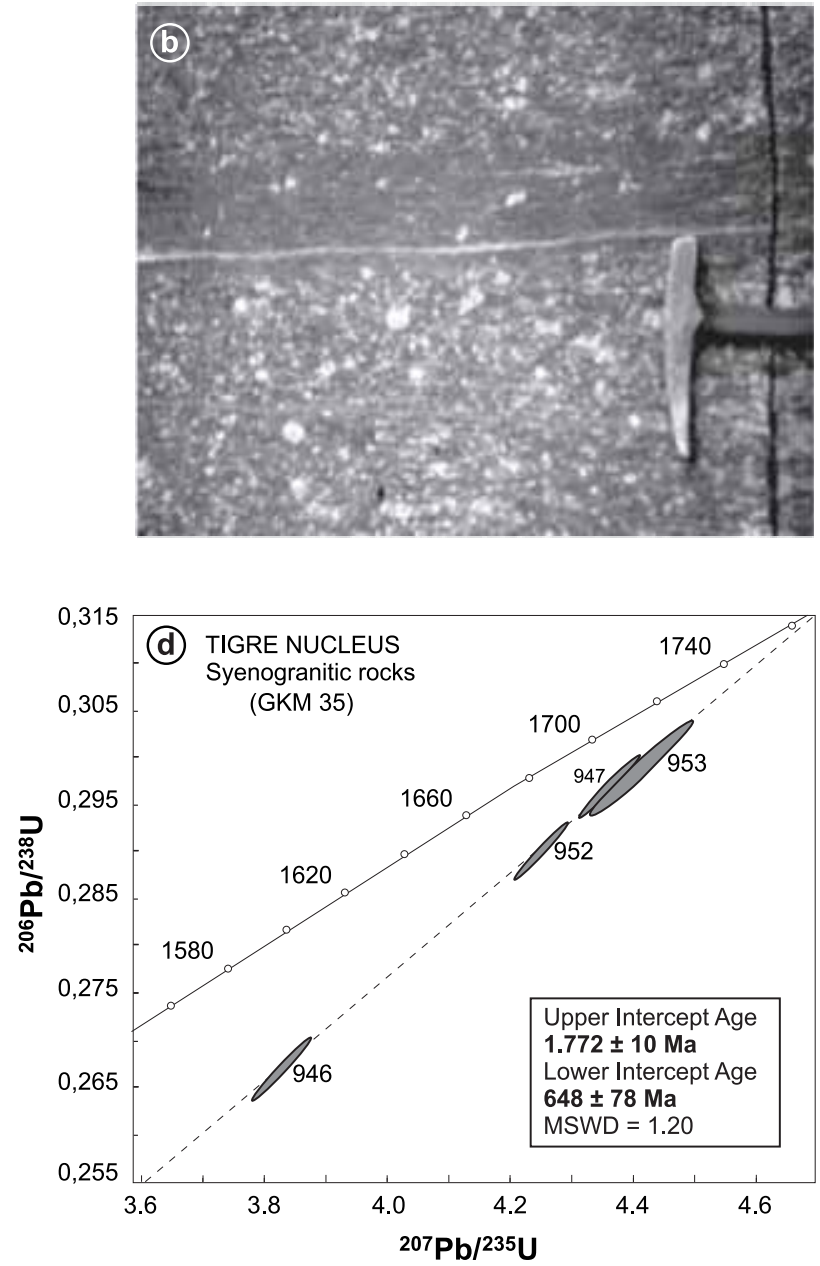

Figure 3. Tigre Nucleus (Kaulfuss, 2001; Cury et al., 2002): a. protomylonitic syenogranite, b. deformation corridors forming proto-mylonites to mylonitic belts, c, d. Zircon U-Pb analyses-ID-TIMS (c: mylonitic quart-monzodiorite $=$ GKM-15; $d$ : mylonitic syenogranite $=$ GKM-35).

Nucleus, recycling of Archean crust during their formation (Kaulfuss, 2001).

$\mathrm{K}-\mathrm{Ar}$ and $\mathrm{Ar}-\mathrm{Ar}$ ages obtained from amphiboles (618 $\pm 36 \mathrm{Ma}$ and $598 \pm 1.2 \mathrm{Ma})$ and biotites $(557 \pm 10 \mathrm{Ma}$ and $555 \pm 1 \mathrm{Ma}$ ) indicate reheating during the Neoproterozoic and also cooling to temperatures less than $500^{\circ} \mathrm{C} \pm 50^{\circ} \mathrm{C}$ (amphiboles) and $300^{\circ} \mathrm{C} \pm 50^{\circ} \mathrm{C}$ (biotites) in the Ediacaran (Kaulfuss, 2001). Therefore, these terranes were formed during the Paleoproterozoic (2199 $\pm 5 \mathrm{Ma})$ and were reworked during the Brasiliano orogeny.

Four fractions of translucent doubly-terminated crystals with abundant fluid inclusions were extracted from deformed syenogranitic rocks (western border of the Tigre Nucleus; Figure 1c). ID-TIMS U-Pb data form a well defined array in the concordia diagram (Figure 3d, GKM-35; Kaulfuss, 2001;
Cury et al., 2002) and cluster close to an upper intercept with concordia of $1772 \pm 10 \mathrm{Ma}$. The lower intercept with concordia is $648 \pm 80 \mathrm{Ma}$. The upper intercept value of $1772 \pm$ $10 \mathrm{Ma}$ is similar to that observed for the Betara Nucleus rock types of the same nature, indicating widespread formation of syenogranites in the Statherian (Kaulfuss, 2001; Cury et al., 2002). The imprecise lower intercept of $648 \pm 80 \mathrm{Ma}$ is important because it suggests a significant superimposed Neoproterozoic tectonothermal event.

\section{The Apiaí Mirim Nucleus}

The Apiaí Mirim Nucleus occupies the northern portion of the Três Córregos Batholith, in tectonic contact with the Itaiacoca (to the north) and Água Clara (to the south and 
west) metavolcanosedimentary sequences (Figure 1c). It is represented mainly by biotite-amphibole syenogranites and pinkish-gray mylonitic monzogranites containing K-feldspar porphyroclasts with recrystallized rims. The medium- to fine-grained matrix is intensely deformed and is constituted by intercalations of mafic (biotite and amphibole) and quartz-feldspatic levels (Prazeres Filho, 2005).

\section{Geochronology}

Four zircon fractions of clean, transparent, doublyterminated, (long and short) prismatic crystals were analyzed by ID-TIMS. They yielded discordant $\mathrm{U}-\mathrm{Pb}$ ages, with an upper intercept with concordia of $1752 \pm 9 \mathrm{Ma}$. This age is interpreted as the time of igneous crsystallisation of these rocks (Prazeres Filho, 2005).

\section{MESOPROTEROZOIC SEQUENCES}

The widespread Mesoproterozoic terranes are largely distributed in the central and southern sectors of the the Apiaí Terrane are represented by the Betara, Perau, Votuverava, Água Clara metavolcanosedimentary sequences and probably Lajeado sequences (Figure 1c).

\section{The Betara and Perau Metavolcanosedimentary Sequences}

The Betara and Perau metavolcanosedimentary sequences (Piekarz, 1984) occur in the southern portion of the Apiaí Terrane, adjacent to and in tectonic contact with the Betara and Tigre basement cores. The lithostructural stacking of the Perau and Betara metavolcanosedimentary sequences is better understood in areas with mineral deposits and/or occurrences ( $\mathrm{Pb}, \mathrm{Zn}, \mathrm{Ag}, \mathrm{Ba})$, due to more detailed mapping and a large number of drill holes. The lithostratigraphic columns in the Perau and Betara areas reveal a similar internal organization, represented by three main lithologic sequences: 1. the basal metapsammitic sequence, represented by meter-sized units of fine- to medium-grained, relatively pure white quartzites with intercalations of micaceous quartzites (muscovite quartzites), quartz phyllites, graphitic phyllites and rhythmic phyllites, where the $\mathrm{S}_{0}$ primary bedding can still be recognized. Fining-up features and the presence of planar cross stratifications of small to medium angle suggest coastal depositional environments; 2. the middle marbles, calc-silicate and metamarls sequence, directly overlying the quartzitic rocks, with homogeneous to banded light gray marbles with intercalations of calc-silicate rocks in the upper stratigraphic layers. In general, the textures are lepidoblastic to granoblastic and the alternation of quartz-, phyllosilicate- (muscovite and chlorite) and dolomite-rich levels characterize the $\mathrm{S}_{0}$ compositional banding. Fine- to medium-grained graphitic phyllites occur as centimeterto meter-sized layers. There are subordinate fine-grained meta-trachytes that are locally vesicular. Meter-sized sulfide bodies and/or iron formations, as well as finegrained silicatic levels (possibly metachert), sometimes impregnated with iron oxides, are associated with the metavolcanic rocks. Studies carried out by Piekarz (1984) revealed $\mathrm{Cu}, \mathrm{Pb}$, and $\mathrm{Zn}$ anomalies in them; 3. the upper metapelitic sequence, with the predominance of phyllites composed of quartz, sericite-muscovite, biotite, chlorite, garnet, staurolite, graphite, magnetite \pm feldspar with occasional intercalations of calc-silicate and quartzitic rocks and meter-thick sills of metabasic rocks.

\section{Geochronology}

Isotopic studies concerning the Betara Sequence were concentrated on the metabasic rocks that occur intercalated with the upper metapelitic sequence (Figure 4a; Siga Jr. et al., 2011a). One of the rocks analyzed is concordantly intercalated within finely foliated to rhythmic phyllites. It is fine-grained at the rims, medium- to coarse-grained towards the center, and foliated. The five zircon fractions analyzed by ID-TIMS included fractions containing crystals with doubly-terminated prismatic habit, inclusions and a few fractures (fractions with long prisms and fractions with short prisms), as well as fractions with xenomorphic crystals. The resulting data (Figure 4b, LBT-7A; Siga Jr. et al., 2011a) indicate a concordia upper intercept age of 1489 $\pm 11 \mathrm{Ma}$. This Calymmian age is interpreted as the time of zircon crystallization and consequently of the emplacement of these basic rocks. This age is also interpreted as the minimum age for the Betara Sequence deposition.

Six zircon populations were separated from sample LBT9: long fractured prisms with rounded edges containing inclusions, irregular fragments, fractured fragments, rounded crystals, and xenomorphic crystals. The data points are scattered in the Concordia diagram (Figure 4c; Siga Jr. et al., 2011a), where irregular and intensely fractured fractions are concordant at $2698 \pm 21 \mathrm{Ma}$, rounded grains are concordant at $2135 \pm 7 \mathrm{Ma}$, and xenomorphic grains are concordant at $1476 \pm 10 \mathrm{Ma}$. The fractions composed of prismatic grains with rounded terminations, and the other fragments are very discordant. We believe that the older fractions were probably captured from wall rocks forming the basement to the Betara sequence by the basic magma during its ascent through the crust. The younger xenomorphic fraction is similar to that found in other basic rocks, and the crystallization age obtained is similar to the found for sample LBT-7. 
Sm-Nd analyses of the Betara Sequence metabasic rocks revealed low $\mathrm{Sm}$ contents (1.0 to $1.6 \mathrm{ppm}) . \varepsilon_{\mathrm{Nd}}$ values, when calculated for $\mathrm{t}=1400 \mathrm{Ma}$ are positive, varying between +2 and +5 , suggesting periods of mantle differentiation and formation of crustal protoliths that are close in time to those of formation of the metabasic rock types. Additionally, Kaulfuss (2001) obtained K-Ar ages of $604 \pm 11$ Ma and Ar-Ar of
$614 \pm 2$ Ma from muscovites of the Betara Sequence quartzites, which developed along low- to medium-angle-dipping planes, characterizing the involvement of these rocks in the Neoproterozoic thermo-tectonic events.

Zircon crystals of the medium- to coarse-grained metabasic rock intercalated with the Perau Sequence metasediments were analyzed by the U-Pb SHRIMP
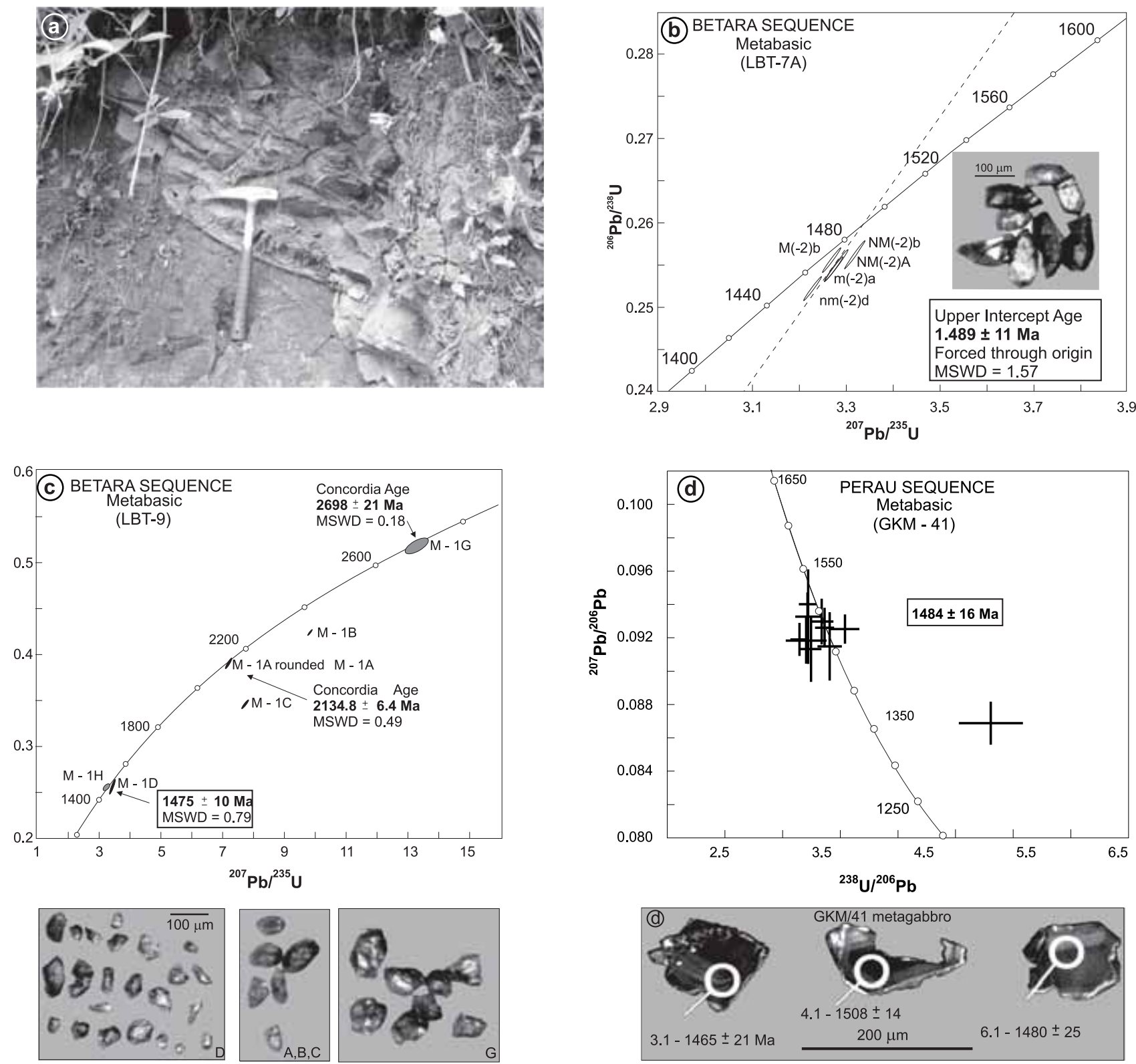

Figure 4. a. Betara Sequence - metabasic rocks intercalated within upper metapelitic unit, b, c. Zircon U-Pb ID-TIMS analyses of the Betara Sequence metabasic rocks (b: LBT-7A; c: LBT-9; photomicrographs of representative zircons are shown; Siga Jr. et al., 2011a), d. Zircon U-Pb SHRIMP analyses of the Perau Sequence metabasic rocks (G KM-41; Images obtained by cathodoluminescence; Kaulfuss, 2001). 
method. Images obtained by cathodoluminescence and transmitted light reveal misshapen zircon crystals with oscillatory zoned structure suggesting igneous growth. Both internal and external domains were analyzed, resulting in a concordant age of $1484 \pm 16 \mathrm{Ma}$ (Kaulfuss, 2001; Figure $4 d)$, in agreement with the age obtained for the Betara Sequence metabasic rocks.

\section{The Votuverava Metavolcanosedimentary Sequence}

The low-grade metasediments distributed between the Lancinha (to the south) and Morro Agudo, Ribeira and Agudos Grandes shear zones (to the north) are referred to in the literature as the Votuverava Formation (Figure 1c). It consists mainly of metapelitic rocks (sericite schists, phyllites, slate), with subordinate intercalations of locally conglomeratic metasandstones, rare carbonatic rocks and frequent metabasites. The contact relationships between the Votuverava Sequence and the Betara and Perau Sequences are unclear. Despite the differences in rock types, Ebert, Hasui and Quade (1988) recognized a common tectonometamorphic history, admitting gradational transitions between these units. A large number of works, however, infer the Votuverava Sequence to be younger than the Betara and Perau Sequences.

Fiori (1990) subdivided the Votuverava Sequence into three main lithologic units, described from bottom to top as Bromado Sequence (phyllites, quartzites, metaconglomerates and phyllonites), Coloninha Sequence (the most important - metasandstones, metasiltites, metarhythmites and metaconglomerates) and Saivá Sequence (carbonaceous phyllites, dark gray marbles, metamarls and carbonatic metarhythmites). Metabasic rocks occur structurally concordant with the metapelitic sequences, probably represent sills (Figures 5a, 5b). They comprise tremolite/actinolite, plagioclase, chlorite and epidote, indicating greenschist-facies metamorphism. They have geochemical affinity with sub-alkaline tholeiitic basalts, suggestive of extensional environments (Maniesi and Oliveira, 1998; Basei et al., 2003; Siga Jr. et al., 2011b).

\section{Geochronology}

ID-TIMS U-Pb analysis was undertaken on detrital zircons from Votuverava Sequence values quartz-mica schists. The zircon crystals were grouped in four distinct populations; short prisms with rounded edges, translucent prismatic crystals, opaque prismatic crystals and rounded crystals. Most ages concentrated between 1940 - 1760 Ma, indicative of Paleoproterozoic source areas. One population of opaque crystals with an age of $\sim 2670 \mathrm{Ma}$, indicated
Archean sources. Basei et al. (2008) dated the detrital zircons individually by SHRIMP and obtained populations with ages close to $1750 \mathrm{Ma}, 2200$ - $1900 \mathrm{Ma}, 2400 \mathrm{Ma}$ and $3200-2800 \mathrm{Ma}$. The $1750 \mathrm{Ma}$ age can be interpreted as the maximum sedimentation age of the Votuverava Sequence, which is similar to the zircon ages obtained for syenogranitic and metabasic rocks of the Tigre, Betara and Apiaí Mirim basement nuclei.

ID-TIMS U-Pb zircon ages have been obtained for metabasic rocks of two localities of the Votuverava Sequence (Basei et al., 2003; Siga Jr. et al., 2011b). For a metabasic rock of the central-southern portion an age of $1451 \pm 39$ Ma was obtained from regression of data on three very clean and prismatic zircon fractions (Figure 5c, HCM01 ), and is interpreted as the time of igneous intrusion of the basic body. The other metabasic body (sample HCM16) comes from the north, close to the Perau Nucleus. Four (prismatic and clean) zircon fractions were analyzed and yielded concordant within error ages, at $1479 \pm 12 \mathrm{Ma}$, which is also interpreted as relative to the time of zircon crystallization and emplacement of this body (Figure 5d, HCM-16). Minimum ID-TIMS zircon U-Pb ages of 603 \pm 23 Ma were obtained for the Varginha granitic body intrusive in the Votuverava metavolcanosedimentary sequence (Basei et al., 2003; Siga Jr. et al., 2011b).

\section{The Água Clara Metavolcanosedimentary Sequence}

The metavolcanosedimentary rocks of the Água Clara Sequence occur south of the Itapirapuã Shear Zone, being limited to the south by the Morro Agudo and Quarenta Oitava shearzones(Figure 1c).Pureandimpuremarblespredominate, but there are also calc-silicate rocks, calc-schists, metamarls, metacalcarenites, mica schists, amphibole schists, quartzites, metacherts, metabasites and amphibolites. Two facies can be identified and are named São Silvestre and Serrinha (Fiori, 1990). The basal São Silvestre facies is represented by quartz-mica schists, fine quartzites and phyllites, and additionally impure marbles, metamarls and metabasic rocks. This unit has manganese- and iron-rich levels. In the Serrinha facies carbonatic rocks predominate with rare intercalations of clastic rocks. The suggested deposition environment is of shallow waters, considering the frequency of dolomitic levels with presence of sedimentary breccia and cross stratification. The regional metamorphism is medium grade, amphibolite facies. The metabasic and amphibolitic rocks investigated occur as elongated bodies concordant with the regional framework of the metacarbonate rocks (Figures 6a, 6b). They are greenish-gray, fine- to mediumgrained, rarely coarse-grained and, contain amphibole (hornblende) usually transformed to biotite and/or chlorite, 

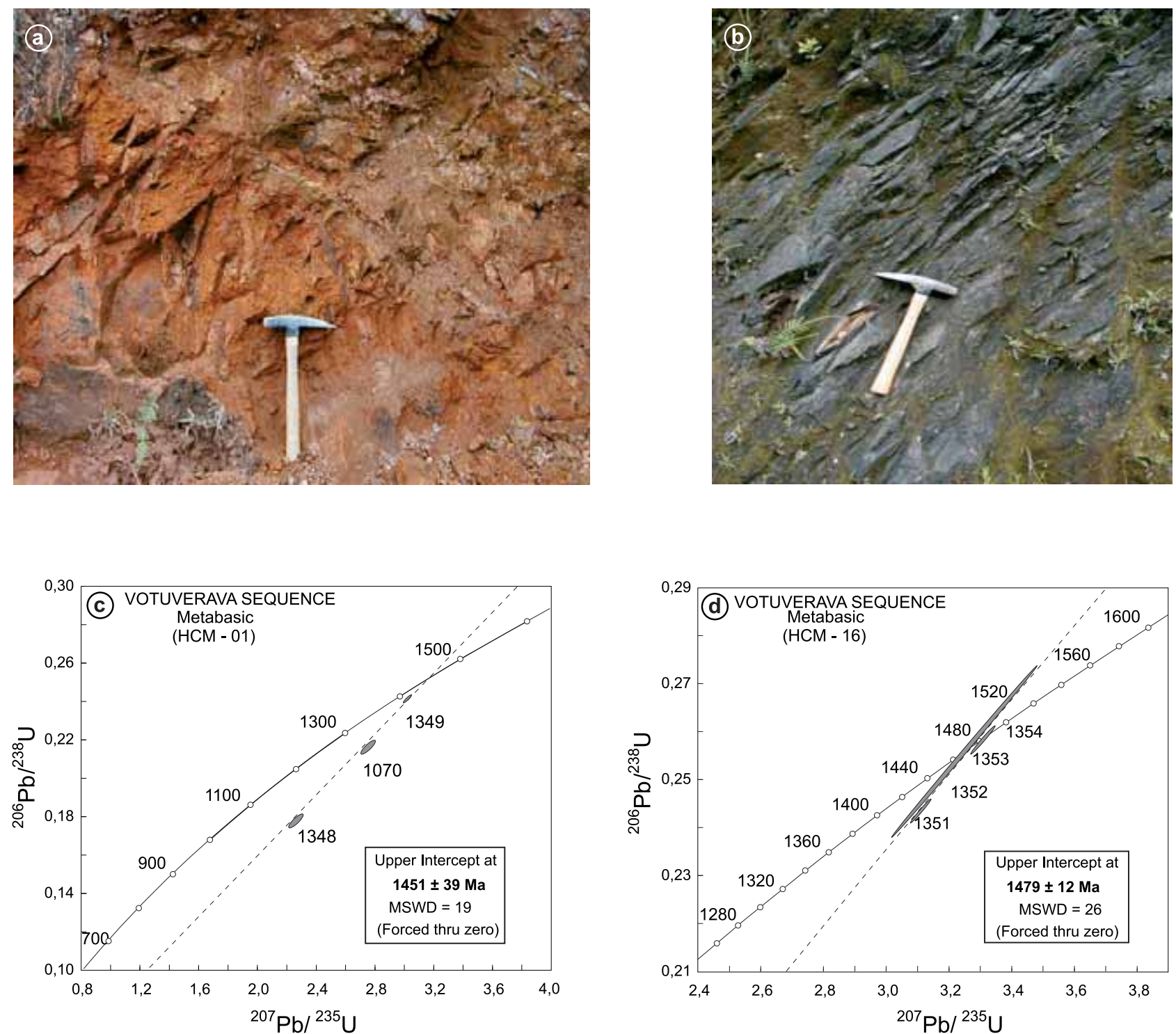

Figure 5. Votuverava Sequence: a. metabasic rocks, b. phyllites rocks, c, d. Zircon U-Pb ID-TIMS analyses of the metabasic rocks (c: HCM-01; d: HCM-16; Siga Jr. et al., 2011b).

saussuritized plagioclase (albite-oligoclase), and in larger or smaller proportion quartz, sericite, garnet, diopside, zircon, titanite, opaque minerals, epidote and carbonate. They usually present relict igneous features, such as ophitic and subophitic textures, and clinopyroxenes, calcic plagioclase, as well as orthopyroxene and hornblende. The geochemical data suggest a tholeiitic character, possibly associated with extensional settings (Frascá et al., 1990; Weber et al., 2003).

The Três Córregos Batholith is intrusive in the metavolcanosedimentary rocks of the Água Clara Sequence(Prazeres Filho, 2000, 2005). Abundant xenoliths of the calc-silicate rocks, previously metamorphosed and folded, confirm that the intrusion is younger than the Água Clara Sequence.

The bodies of metabasic rocks analyzed are deformed together with the adjacent metasedimentary rocks.

\section{Geochronology}

ID-TIMS, EV-TIMS and SHRIMP techniques were used in the dating of zircons from metabasic sample rocks. This body is fine- to fine-medium-grained, dark gray and is predominantly composed of plagioclase $\left(\mathrm{An}_{30-50}\right)$, 

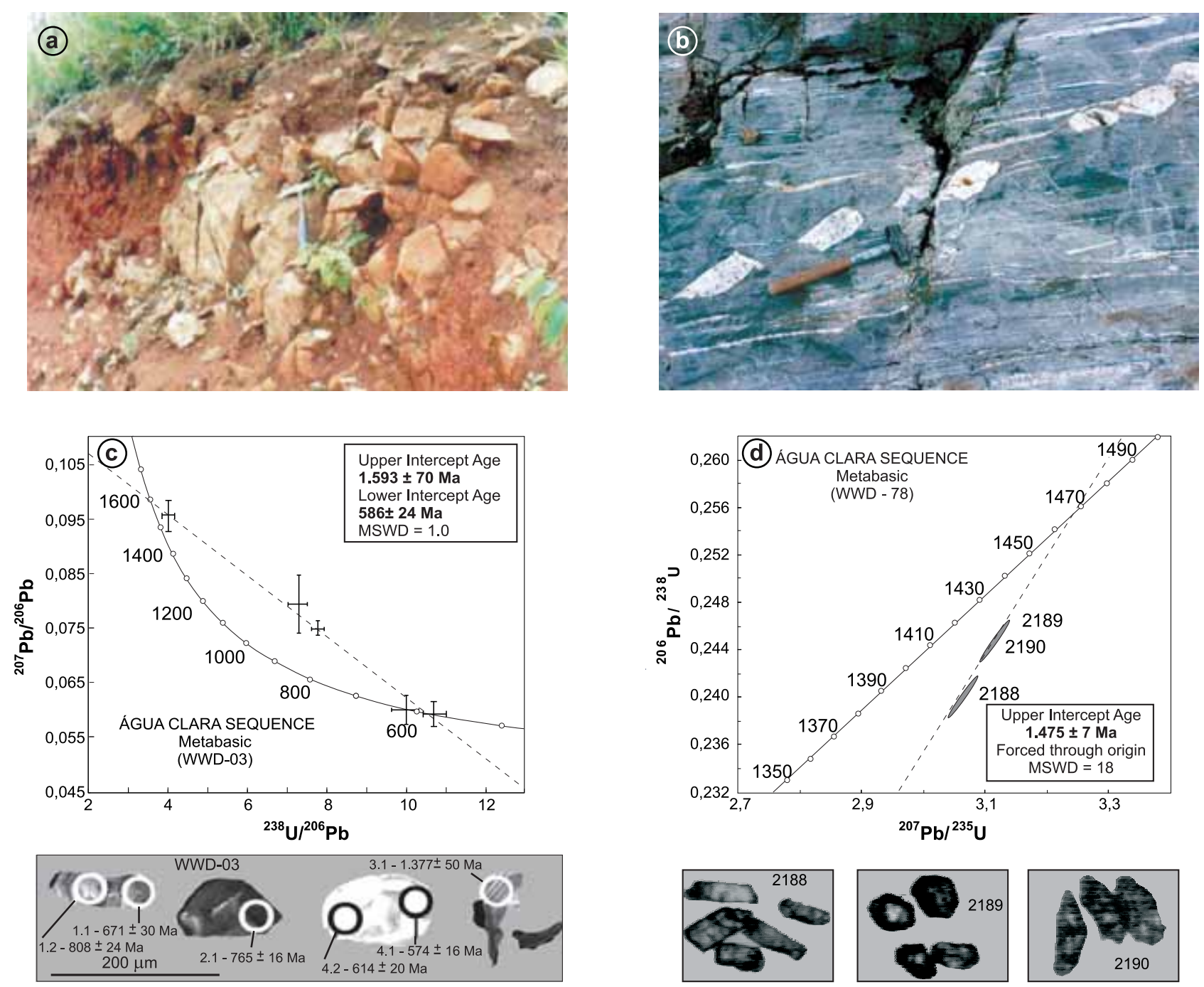

Figure 6. Água Clara Sequence: a. metabasic rocks, b. metacarbonatic rocks, c., d. zircon U-Pb analyses of the metabasic rocks (c: SHRIMP - Tera-Wasserburg diagram and cathodoluminescence images; WWD-03; d: ID-TIMS - Concordia diagram and transmitted light microscope images; WWD-78; Weber et al., 2003); 150-200 $\mu \mathrm{m}$ zircons are shown.

amphibole (hornblende and actinolite), clinopyroxene (augite and diopside), chlorite and epidote. It occurs within rock sequences of carbonatic nature. The zircon crystals are pale gray, with poorly-developed edges and double terminations and are usually inclusion- and fracture-rich.

The SHRIMP U-Pb data plotted along a discordia (Figure 6c; WWD-03) and indicate an upper intercept intercept age of $1593 \pm 70 \mathrm{Ma}$ and $586 \pm 24 \mathrm{Ma}$ for the lowerintercept (Weber etal., 2003). Cathodoluminescence studies revealed the presence of nuclei and overgrowth in practically all the crystals analyzed (Figure 6c). The point closest to the upper intercept corresponds to a xenomorphic crystal, commonly observed in rocks of basic nature, with growth lines suggesting igneous crystallization. The other analyses correspond to the inner portions of the zircon crystals with idiomorphic characteristics. Thus the Calymmian age obtained (1593 $\pm 70 \mathrm{Ma})$ is interpreted as that of zircon crystallization and formation of these rocks. The Ediacaran age (586 $\pm 24 \mathrm{Ma}$ ), defined in the overgrowth zones, reflects the Brasiliano Cycle overprinting. U-Pb data obtained for four zircon populations of the same body by means of ID-TIMS are distributed along a discordia with an upper intercept with concordia of $1561 \pm 18 \mathrm{Ma}$ and a lower 
intercept of $751 \pm 15 \mathrm{Ma}$. The only point that plots close to the lower intercept is left to concordia curve, indicating isotopic disequilibrium. The age of $751 \pm 15 \mathrm{Ma}$ obtained at this intercept must be interpreted with caution and most probably by meaningless (Weber et al., 2003).

The use of the EV-TIMS technique (single-zircon evaporation, Kober, 1986) to analyze zircons of the same body produced a plateau average ${ }^{207} \mathrm{~Pb} /{ }^{206} \mathrm{~Pb}$ age of 1461 $\pm 51 \mathrm{Ma}$. The age obtained is younger than the SHRIMP values, suggesting mixing between the portions with Neoproterozoic overgrowth and Mesoproterozoic nuclei (Weber et al., 2003).

Another metabasic rock occurs as meter-sized bodies intercalated with metacarbonatic rocks. It is usually medium-grained, gray, and composed of plagioclase, amphibole, chlorite, quartz and epidote. ID-TIMS U-Pb data for four zircon populations were obtained. Two fractions consist of translucent crystals with poorly-defined edges, and few inclusions and fractures. In the other fractions relatively well-formed, colorless prismatic zircon crystals predominate, with well-defined edges, and usually with inclusions and/or fractures. The discordia that best fits the analytical points defines an age of $1484 \pm 76 \mathrm{Ma}$ for the upper intercept and of $601 \pm 83 \mathrm{Ma}$ for the lower intercept (Weber et al., 2003) .

Xenoliths of metabasic rocks occur in the Três Córregos Batholith. They are of varied shapes and sizes, dark gray, fine-grained, and composed predominantly of plagioclase and amphibole. Three zircon populations of a meter-sized xenolith were analyzed by ID-TIMS, and indicate an age of $14757 \mathrm{Ma}$ for the upper intercept (Figure 6d; Weber et al., 2003). In this case, Neoproterozoic lower intercept ages were not obtained.

Additionally ID-TIMS U-Pb analyses were carried out on three zircon fractions from 30 to $50 \mathrm{~cm}$ thick units of rhyolitic rocks that occur close to the contact with the Três Córregos Batholith and truncate the metamorphic banding of the Água Clara Sequence calc-silicate rocks. They are fine- to medium grained, light gray, and are composed predominantly of potassic feldspar, quartz and biotite. The zircon crystals are prismatic, translucent and usually contain inclusions and fractures. The data plot close to an upper intercept, with an age of $638 \pm 12 \mathrm{Ma}$ (Weber et al., 2003).

\section{The Lajeado Metavolcanosedimentary Sequence}

The Lajeado Sequence occurs between the Água Clara (to the north-northwest) and Votuverava compartments (to the south-southeast), being delimited by the Ribeira, Figueira and Quarenta Oitava shear zones (Figure 1c). Metamorphosed sandstones, rhythmites, siltites, marls and limestones predominate. These rock types are interpreted as representing a shallow-water platformal sequence with relatively thick, alternating carbonatic and psammo-pelitic layers (Campanha et al., 2008b). The metamorphic grade is low (greenschist), and primary structures such as wave marks and cross stratifications are preserved. Contact metamorphism was produced by the intrusion of the Itaoca granitic massif in the Lajeado Sequence.

Fiori (1992) groups the Lajeado metasedimentary sequences in three units named Tacaniça (clastic rocks), Capivara (carbonatic rocks) and Vuturuvu (clastic rocks), and describes a simpler structural pattern, suggesting that they formed after the thrusting events registered in the other sequences of the Apiaí Domain.

\section{Geochronology}

Campanha et al. (2008b) used the SHRIMP U-Pb method to analyze detrital zircons from the Lajeado Sequence, and obtained close to concordant data with ages of 2200 to $1400 \mathrm{Ma}$. Thus $1400 \mathrm{Ma}$ is the maximum age of deposition. The mimimum age is given by the $877 \pm 7.7$ Ma emplacement age of the Apiaí Gabbro (Campanha et al., 2009). Additionally, Salazar et al. (2004) presented an $\mathrm{U}-\mathrm{Pb}$ SHRIMP age of $623 \pm 10 \mathrm{Ma}$ for the Itaoca granitic massif, intrusive in the Lageado Sequence.

\section{NEOPROTEROZOIC TERRANES}

The Neoproterozoic terranes are represented by the Antinha, Iporanga and Itaiacoca metavolcanosedimentary sequences (Figure 1c).

\section{The Antinha and Iporanga Metavolcanosedimentary Sequence: Geologic and Geochronologic Synthesis}

The Antinha Sequence is distributed between the Lajeado (to the north-northwest) and Votuverava units (to the southsoutheast), immediately north of the Morro Agudo Shear Zone (Figure 1c). Metamorphosed sandstones, rhythmites, siltites, marls and limestones predominate in this unit. The metamorphic grade is low (greenschist) and primary structures such as wave marks and cross stratifications are preserved (Basei et al., 2008). The simpler structural pattern of this unit suggests that these rocks formed after the thrusting events that affected the other sequences of the Apiaí Terrane.

The main geochronologic data available for the Antinha Sequence were obtained by Basei et al. (2008) by means of the SHRIMP U-Pb zircon method on metamarls from north of the Betara region. The detrital zircon ages indicated 
Paleoproterozoic sources (2200 - $1800 \mathrm{Ma}$ ), whereas some 610 - $590 \mathrm{Ma}$ volcanogenic crystals places the deposition of this sequence in the Ediacaran.

The Iporanga Sequence is distributed according to a relatively narrow and elongated belt in the southwest of São Paulo State (Campanha et al., 2004, 2008a). It is delimited to the south by the Agudos Grandes Shear Zone and to the north by the Figueira Shear Zone. Fine metarhythmites predominate with intercalations of metasandstones, metaarkoses and metarhythmites with impure carbonate layers. A polymictic breccia with clasts of phyllites, quartzites, metasandstones, amphibolites, volcanic rocks (which also underlie the Iporanga Sequence), gneisses and granitoids occurs at the base. The metamorphic grade is low (chlorite zone), and the main structures strike NE and dip NW.

$\mathrm{U}-\mathrm{Pb}$ SHRIMP analyses were carried out on zircon crystals from the underlying metavolcanic rock and on two granite clasts of the basal polymictic breccia (Campanha et al., 2008a, 2008b). The age of $573 \pm 34 \mathrm{Ma}$ for the volcanic rock zircons was interpreted as the time of eruption. The zircon crystals from the granite clasts yielded an age of 593 $\pm 15 \mathrm{Ma}$. These results constrain a maximum depositional age for the Iporanga Sequence in the Ediacaran.

\section{The Itaiacoca Metavolcanosedimentary Sequence}

The Itaiacoca Belt is represented by a sequence of metavolcanosedimentary rocks that occurs between the Cunhaporanga (NW) and Três Córregos (SE) Granitic Batholiths, in eastern Paraná and southeastern São Paulo States. The general trend of the belt is NE-SW and is only $\sim 10 \mathrm{~km}$ wide but $\sim 100 \mathrm{~km}$ long (Figure 1c).

The studies carried out in the central-southern portion of the Itaiacoca Belt by Siga Jr. et al. (2009) defined three units from base to top; 1. an association of metacarbonatic rocks, 2. meta-arkoses with an important volcanic contribution and subordinate metaconglomerates, and 3. metapelitic and metapsammitic rocks. The lower association is composed predominantly of dolomitic meta-limestones with intercalations of metamarls (calc-phyllites and carbonatic phyllites), in the upper portions of the unit. In some outcrops a typically centimeter-thick banding is observed, which may represent the original sedimentary stratification. Elsewhere the lower association is massive, with no obvious layering. The metamarls are fine-grained and show $\mathrm{mm}$ to cm-thick banding, characterized by alternating light-gray, dark-gray, pink and white banding. The dolomitic metalimestones may preserve structures such as ripple and lenticular bedding, climbing ripples, ooliths, pisoliths and cross stratification. Banks of stromatolitic marbles occur, in general, with columnar forms (Figure 7a). Sallun Filho and
Fairchild (2004) studied the stromatolites of the southern region of Itapeva recognized two distinct forms of Collenia Itapevensis, one of which Conophyton Garganicum, is found in the lower Neoproterozoic and Mesoproterozoic strata in other parts of the world. Soares, Stevanato and Camargo (1987) interpret this sequence as part of a shallow-water, platform. In the proximity of the Cunhaporanga Granitic Batholith, the metamorphosed dolomitic limestones are talc- and tremolite-rich, indicating contact metamorphism. Light-green chlorite-sericite phyllites and metabasic rocks occur concordantly intercalated with the metacarbonate sequence. In the metabasic rocks the plagioclase and pyroxene crystals are partially or totally transformed (actinolite, epidote/zoisite, chlorite and more rarely biotite), indicating greenschist-facies metamorphism, chlorite and biotite zones. Petrographic and geochemical studies carried out by Reis Neto (1994) indicate sub-alkaline tholeiitic basalt compositions, suggesting formation in an extensional environment.

The intermediate unit consists of meta-arkosic rocks with intercalations of metavolcanic and metavolcaniclastic rocks and lenses or even meter-thick layer of conglomeratic metasandstone, with pebbles of volcanic rocks and subordinate quartz and metapelite pebbles. The pebbles are angular to well-rounded, varying from millimetric to centimetric $(\sim 15 \mathrm{~cm})$. Pebbles of carbonatic rocks have not been found in these metaconglomerates. The fine sericite and chlorite in the matrix indicate chlorite zone greenschist-facies metamorphism. The metavolcanic rocks occur as flows of varied thickness, intercalated with metapsammitic rocks and showing sharp contacts. Narrow light-green phyllitic levels (possibly volcanic ashes), as well as metavolcanic rocks with clasts of volcanic material (pyroclasts) are observed. The volcanic layers usually contain abundant amygdales/ vesicles, which are frequently stretched. These rocks contain a large quantity of K-feldspar (sanidine), opaque minerals and devitrified material. The vesicles are usually filled with sanidine, quartz, biotite, carbonates and opaque minerals. The main metamorphic paragenesis is characterized by chlorite, sericite and more rarely biotite. These are probably trachytes of alkaline composition, suggesting an extensional continental-rift setting. They present high contents of potassium (6 to $12 \%$ ) and other LIL elements, indicating ultrapotassic character (Reis Neto, 1994).

The upperassociation consists mostly of orthoquartzites, fine- to medium-grained white metasandstones, with intercalations of brown to light-green sericite phyllite, graphiticphyllites, sandy-pelitic metarhythmites, metasiltite and metargillite. They preserve original structures, such as horizontal lamination, normal microgradational bedding and low-angle cross lamination. The contact between this unit and the metasandstones seems to be gradational. 

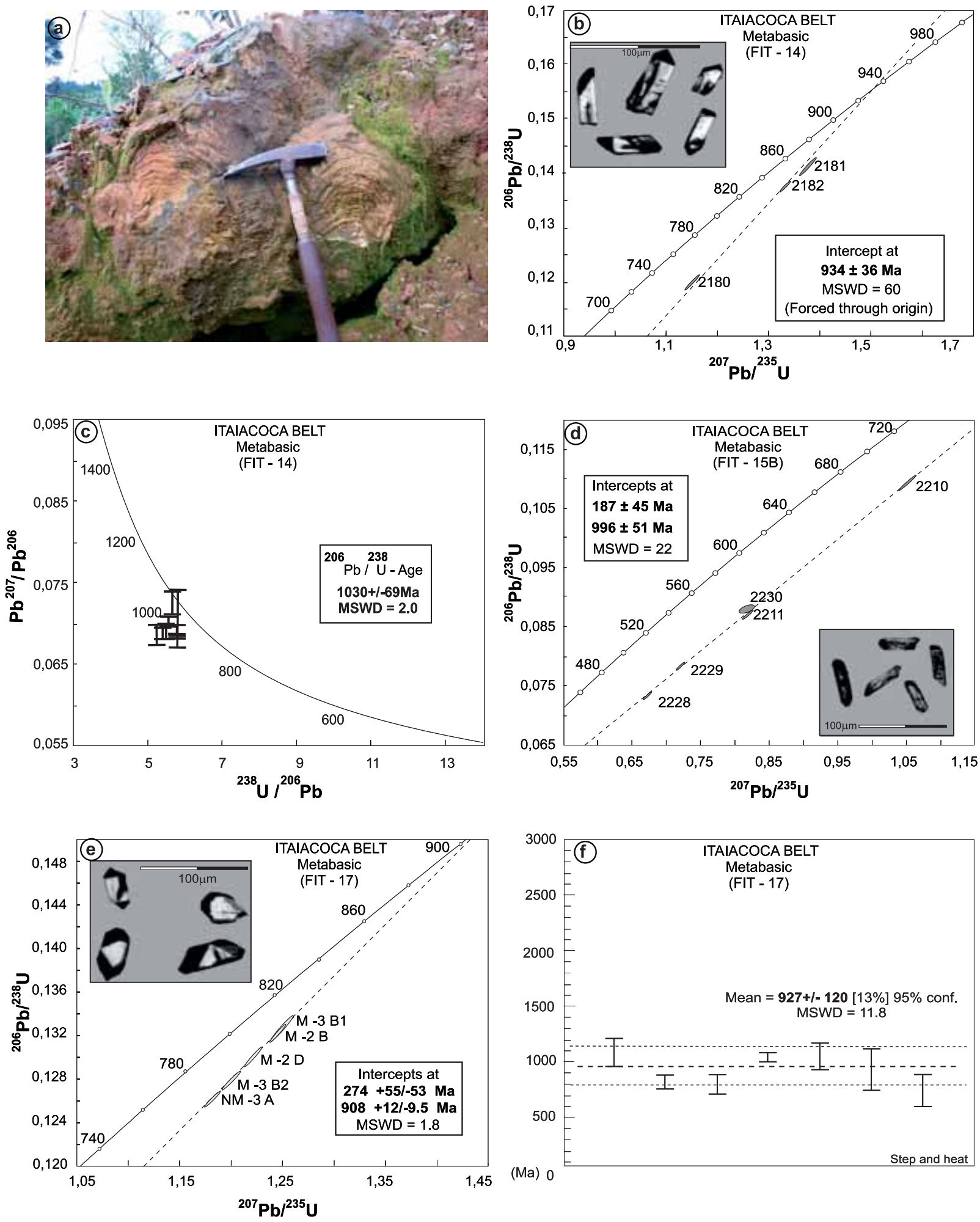

Figure 7. Itaiacoca Sequence: a. Stromatolites in dolomitic marbles, b, d, e. Concordia diagram (U-Pb ID-TIMS analyses) of zircon of metabasic rocks, c. Tera-Wasserburg diagram (SHRIMP analyses) of zircon of metabasic rocks, f. Heat step diagram (EV-TIMS analyses; Kober, 1986) of single zircon of metabasic rocks. All images of zircon obtained by optical microscope (Siga Jr. et al., 2009). 
The primary structures (gradational banding, climbing, cross stratification, amygdales/vesicles and stromatolites) define the original bedding (S0) in metasedimentary sequences of the Itaiacoca Belt. Foliation S1 is defined by the alignment of sericite, chlorite, as well as by stretching of amydales/vesicles. Foliation S1 is folded and in some places crenulated, developing an axial-planar cleavage (S2).

\section{Geochronology}

$\mathrm{U}-\mathrm{Pb}$ zircon dating of the carbonatic sequence (lower association) was based on three occurrences of metabasic rocks that are concordantly intercalated with metamorphosed dolomitic limestones of the southern portion of the Itaiacoca Belt(Siga Jr. etal., 2009). The metabasic rock(FIT-14, Figure $7 b$; Siga Jr. et al., 2009) has translucent zircons with tabular habits, poorly developed edges and terminations, with rare inclusions and fractures. ID-TIMS dating of different zircon fractions yielded discordant ages which when regressed yield an upper concordia intercept age of $934 \pm 36 \mathrm{Ma}$ (Figure 7b). Zircons were also dated by SHRIMP technique (Beijing SHRIMP Center, Beijing China), and yielded a weighted mean ${ }^{206} \mathrm{~Pb} /{ }^{238} \mathrm{U}$ age of $1030 \pm 69 \mathrm{Ma}$ (FIT-14, Figure 7c; Siga Jr. et al., 2009). ID-TIMS U-Pb analyses of zircons from the metabasic rock (FIT-15, Figure 7d; Siga Jr. et al., 2009) morphologically similar to those from FIT-14, yielded an upper concordia intercept of $996 \pm 51 \mathrm{Ma}$. Similarily, for sample FIT-17 (Figure 7e; Siga Jr. et al., 2009), translucent prismatic zircon crystals with well-developed edges and double terminations and with rare inclusions and fractures indicate an age of $908 \pm 12 \mathrm{Ma}$. Additional analysis by means of EV-TIMS was carried out on FIT-17 zircons (Figure 7f; Siga Jr. et al., 2009). The resulting errors were relatively high, and the calculated average age was ca. $930 \mathrm{Ma}$. Zircon $\mathrm{U}-\mathrm{Pb}$ ages obtained for these metabasic rocks are interpreted to show igneous crystallization in the interval 1000 - $900 \mathrm{Ma}$. This establishes the Tonian as the youngest period possible for the deposition of the carbonatic rocks. $\mathrm{Nd} \mathrm{T}_{\mathrm{DM}}$ model ages for these basic rocks are 2100 - $2000 \mathrm{Ma}$ (Reis Neto, 1994). This suggests contamination by older continental basement during the ascent of the magmas.

SHRIMP U-Pb dating of detrital zircons from the metapsammitic sequence (upper association) gave ages concentrated in the 3500 - $3200 \mathrm{Ma}$ and $2200-1900 \mathrm{Ma}$ intervals, with no Neoproterozoic grains detected (Basei et al., 2008).

Zircon dating was undertaken on the following intercalated volcanic rocks (Siga Jr. et al., 2009): finely foliated gray to pinkish-gray rocks containing strongly stretched, millimeter-sized vesicles and amygdales (AB-1 and 07B); slightly deformed, coarse-grained rocks with centimeter-sized varioles (07A; Figure 8a), and a finely foliated type with sporadic presence of varioles (Hot - 2). Zircons from metavolcanic rocks AB-1, 07A and 07B were dated by SHRIMP, with the choice of sites chosen using cathodoluminescence and transmitted light images. Well-formed, prismatic, elongated, light zircon crystals predominate, having well-developed oscillatory zoning but also some turbid domains. Well-preserved domains yilelded ${ }^{206} \mathrm{~Pb} /{ }^{238} \mathrm{U}$ ages of $645 \pm 30 \mathrm{Ma}$ (Figure 8b; sample 07B; Siga Jr. et al., 2003, 2009), $641 \pm 11$ Ma (Figure 8c; sample 07A; Siga Jr. et al., 2003, 2009), and 628 $18 \mathrm{Ma}$ (Figure 8d; sample AB-1; Siga Jr. et al., 2003, 2009). Two xenocrystic zircons in sample AB-1 have ages of of 2480 $\mathrm{Ma}$ and $1900 \mathrm{Ma}$. Inclusion-rich, prismatic, elongated, zircons from metavolcanic rock (sample Hot-2) were analyzed by ID-TIMS, and yielded an age of $636 \pm 30 \mathrm{Ma}$ (Figure 8e; Siga Jr. et al., 2003, 2009), within error of the ages obtained for samples dated by SHRIMP.

These 645 - $628 \mathrm{Ma}$ Neoproterozoic ages are interpreted as related to the time of zircon crystallization and consequently of formation of these volcanic rocks. K-Ar dating of fine $(<2 \mu \mathrm{m})$ sericites from Itaiacoca Belt phyllites and metavolcanic rocks gave 628 - 610 Ma ages shows these rocks have not undergone significant heating following the end of the Neoproterozoic (Basei, unpublished). These rocks have $\varepsilon_{\mathrm{Nd}}$ values of -20 to -17 at ca. $630 \mathrm{Ma}$, and $\mathrm{T}_{\mathrm{DM}}$ model ages in the 2800 - 2600 Ma interval (Reis Neto, 1994). This indicates a major contribution to them from melting of much older crust.

\section{INTEGRATION AND DISCUSSION}

The Apiaí Terrane protomylonitic igneous rocks of the granitic-gneissic nuclei (Apiaí Mirim, Betara and Tigre Nuclei) formed in the Rhyacian ( $2200 \mathrm{Ma})$, with Meso- to Neoarchean inheritance ( 2800 Ma). Within these nuclei, there are Statherian (1790 - $1750 \mathrm{Ma})$ syenogranites and metabasic rocks with geochemical signatures indicative of extensional regimes. These basement inliers have tectonic contacts with the overlaying metavolcanosedimentary sequences (Betara, Perau, Votuverava, Água Clara and Lajeado), whose minimum sedimentation ages are constrained by zircon dating to the Mesoproterozoic (1600 - $1450 \mathrm{Ma}$ ). Thus extensional basins (continental rifts) were initiated at the end of the Paleoproterozoic (1790 - $1750 \mathrm{Ma}$ ) and that during the Mesoproterozoic (1600 - $1450 \mathrm{Ma})$ and they evolved into to basins where the main Apiaí Terrane metasedimentary sequences were deposited. The $\varepsilon_{\mathrm{Nd}} \times \varepsilon_{\mathrm{Nd}}$ diagram (values calculated for $\mathrm{t}=1450 \mathrm{Ma}$; Figure 9a; Siga Jr. et al., 2011b) for metabasic rocks form a group close to the origin with mainly positive values of $\varepsilon_{\mathrm{Nd}}$ and relatively small $\varepsilon_{\mathrm{Nd}}$ values. This suggests that the basic rocks were formed from mesoproterozoic juvenile material extracted from depleted mantle and then emplaced as sills and dykes 

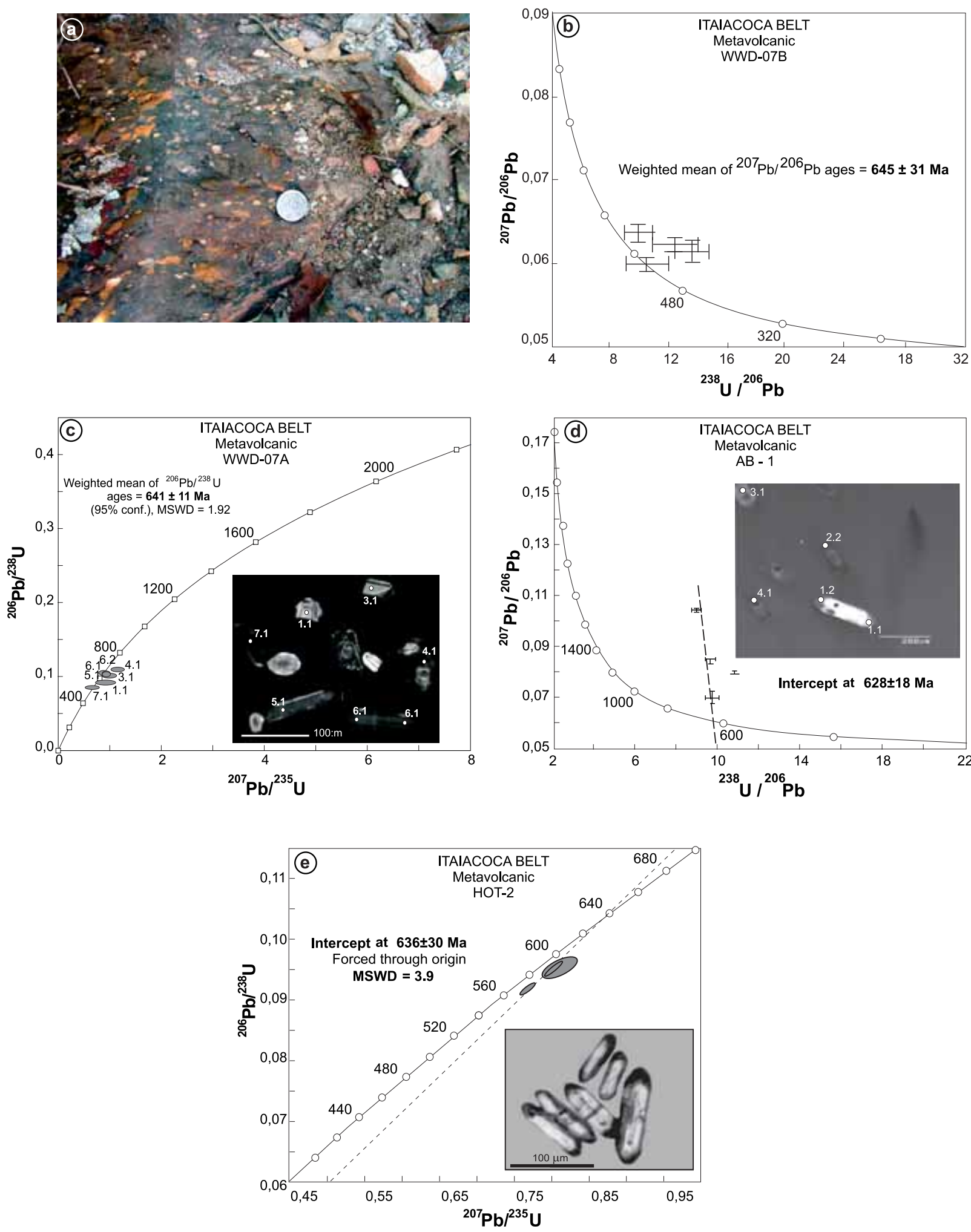

Figure 8. Abapã Sequence metavolcanic rocks: a. amygdales of metavolcanic rocks, b, c, d. Zircon U-Pb SHRIMP analyses (zircon images obtained by cathodoluminescence), e. Zircon U-Pb ID-TIMS analyses (images of zircon obtained by optical microscope); Siga Jr. et al. (2009). 
in the Agua Clara, Votuverava, Perau and Betara paleobasin. On the other hand, negative $\varepsilon_{\mathrm{Nd}}$ values and old $\mathrm{Nd}$ model ages (Tdm) obtained for the Itaiacoca metabasic, Votuverava phyllites, Betara and Tigre granites/syenogranites and Atuba gneiss suggest a long period of crustal residence for their protoliths (Figure 9b; Siga Jr. et al., 2011b).

In the South American continent geologic records of similar ages and tectonic regimes occur in the Serra do Itaberaba Group, Borborema Province, Espinhaço System, Chapada Diamantina Group, São João Del Rei Group, Tocantins Province, Dom Feliciano Belt in Uruguay, and Nico Perez Terrane in Uruguay (Brito Neves et al., 1995; Juliani et al., 2000). This is also observed in once contiguous West Africa, such as the belts developed at the borders of the Congo Craton and south of the Kalahari Craton (Kaoko and Damara Belts: Tegtmeyer and Kröner, 1985; Chemale Jr. et al., 2003; Seth et al., 2005; Seth, Jung, Gruner, 2008; Kröner et al., 2004; Becker et al., 2006; Goscombe and Gray, 2007) , south of the Kalahari Craton (Hanson et al., 2004a, 2006), SE of the Congo Craton and the Central Africa-Kibaran Belts (Alonso and Theunissen, 1998; Kokonyangi et al., 2006), Kaapvaal Craton (Hanson et al., 2004b; Mapeo et al., 2004), W Anti-Atlas/Marocco (Gasquet et al., 2004), SE of the West Africa Craton (Caby, 2003) and Northern Zimbabwe Cráton (Oliver et al., 1998), Figure 1a.

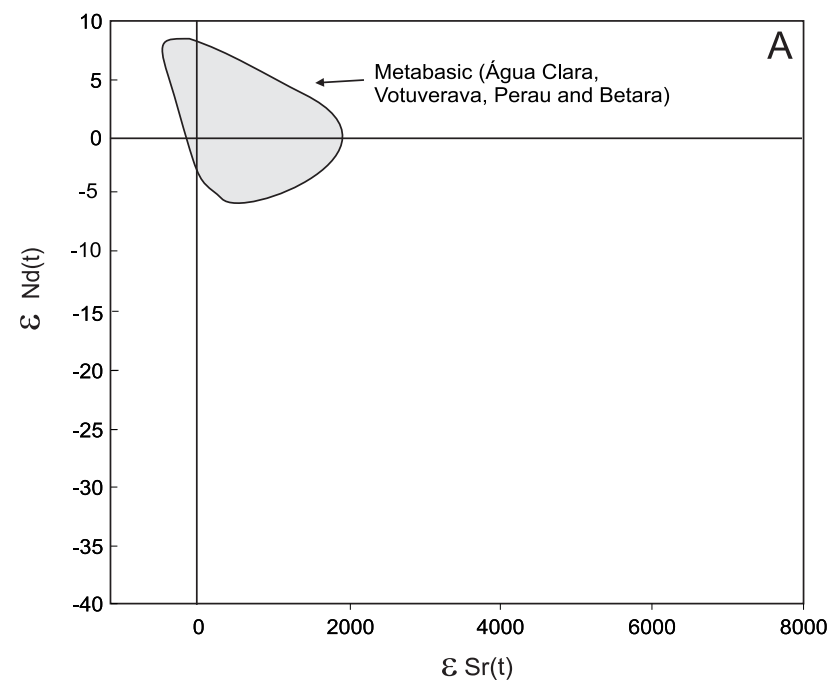

Thiswidespreadrifting withassociatedbasindevelopment is related to mid-Proterozoic breakup of the Paleoproterozoic Columbia Supercontinent (Rogers and Santosh, 2002).

It is worth stressing that in the Itaiacoca Belt two temporarily distinct units are recognized. The first represents a carbonatic platform association with a minimum deposition age of 1030 - $900 \mathrm{Ma}$ (Stenian-Tonian transition). The second is predominantly metapsammitic with metavolcanic intercalations, and was deposited much later at 645 - $628 \mathrm{Ma}$ (Cryogenian/Ediacara). Therefore it is proposed that the term Itaiacoca Formation be restricted to the calcitic and dolomitic metacarbonate rocks and the term Abapã Formation be used for the younger meta-arkoses, metavolcanic rocks and phyllites. A distinct pattern is also observed for the Iporanga Sequence, where ages of granitic clasts from the basal breccias are Neoproterozoic, indicating maximum deposition ages close to $600 \mathrm{Ma}$ (Campanha et al., 2008a, 2008b).

Thus based on available radiometric data, notably $\mathrm{U}-\mathrm{Pb}$ zircon, a chronostratigraphic scenario can be presented for the Apiaí Terrane metavolcanosedimentary sequences and adjacent units represented by Atuba Complex, and their cover including the Capiru and Turvo-Cajati Sequences (Figure 10). The polycyclic evolution of the southern portion of the Apiaí Terrane is evident. Paleoproterozoic crystalline basement (Rhyacian-Orosirian) is present in tectonically-bounded

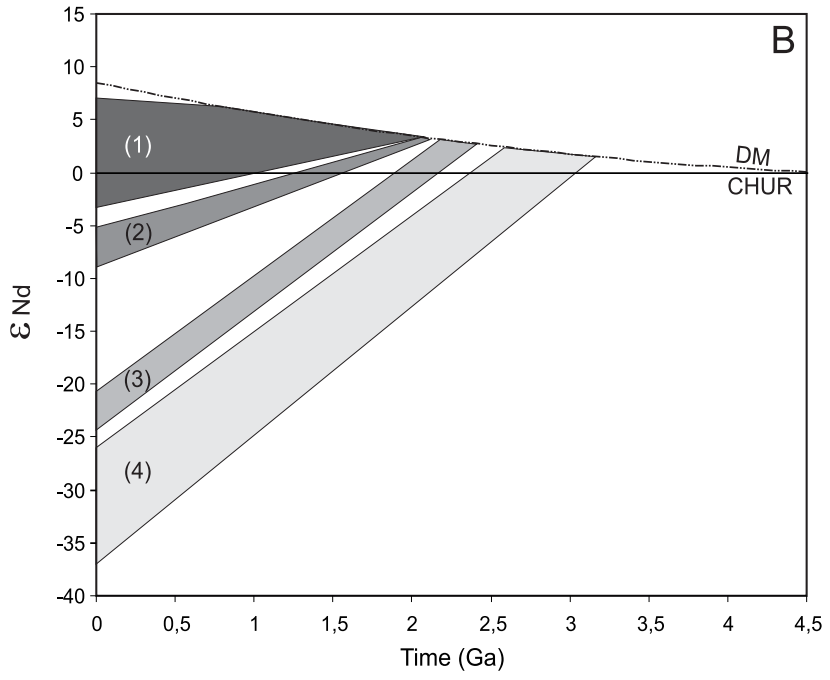

(1) Água Clara, Votuverava, Perau Betara metabasic

(2) Itaiacoca metabasic

(3) Votuverava metapelitic

(4) Betara and Tigre Nuclei: granite/gneiss and syenogranite and Atuba Complex gneiss/migmatite

Figure 9. a. Epsilon Nd vs. Epsilon Sr diagrams (values calculated for $t=1450 \mathrm{Ma}$ ), b. Epsilon $\mathrm{Nd}$ vs. Time diagram (De Paolo, Linn, Chubbert, 1991). 

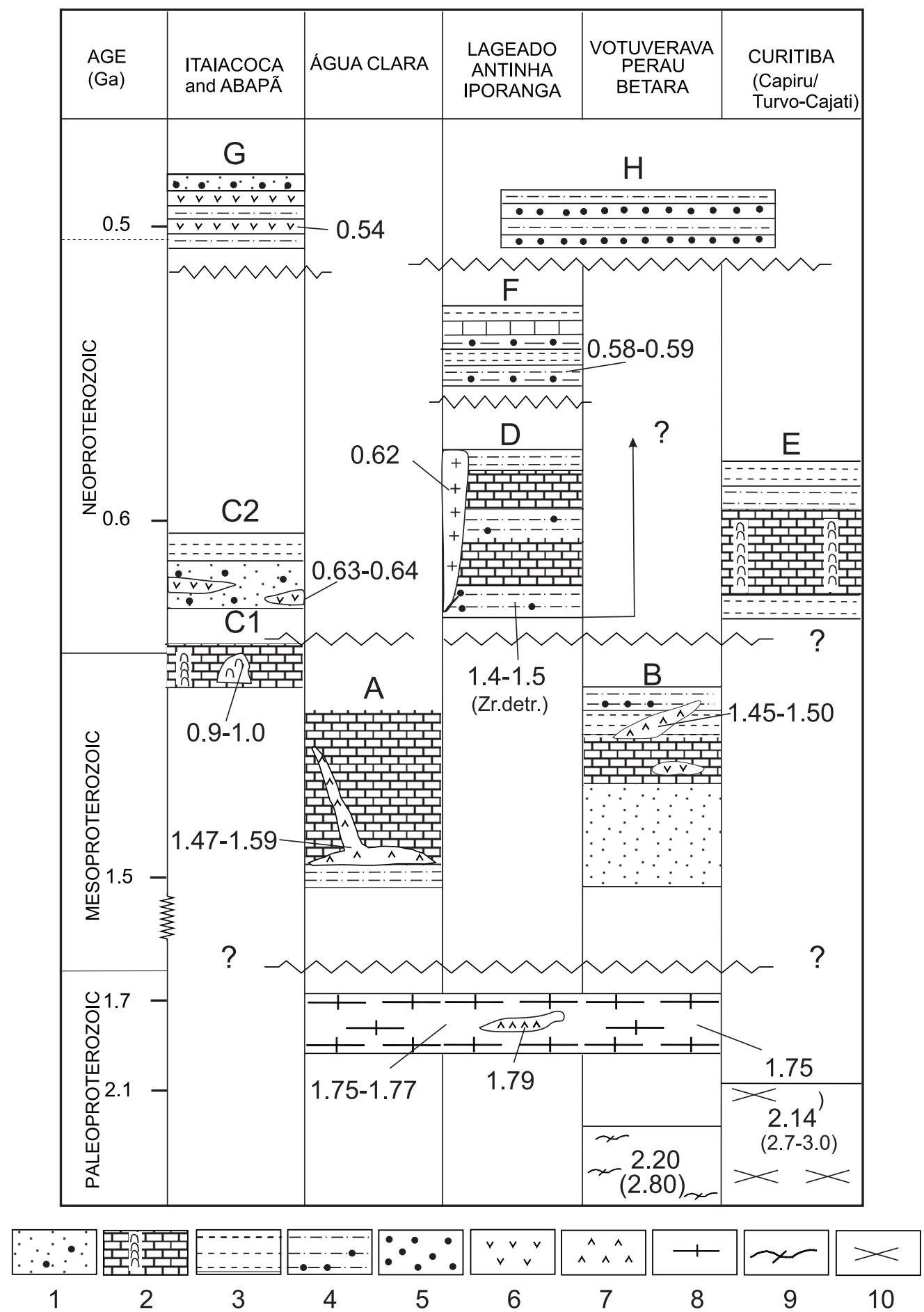

Figure 10. Proposed Stratigraphic Columns for the Southern Ribeira Belt: Major metasedimentary units: A. Água Clara Sequence, B. Votuverava Perau and Betara Sequences, C1. Itaicoca Sequence, C2. Abapã Sequence, D. Lajeado Sequence, E. Capiru Sequence, F. Iporanga and Antinha Sequences, G. Castro Group, H. Camarinha Formation (1. metapsammitic sequences, metaconglomerates levels when marked; 2. marbles, metamarls sequences with stromatolites when marked; 3. metapelitic sequences; 4. metapelitic/metapsammitic sequences, metaconglomerates when marked; 5. metaconglomerates sequences; 6. felsic metavolcanics; 7. metabasic rocks; 8. deformed A type granitic rocks; 9. deformed granitic rocks; 10. gneissic-migmatitic rocks of Atuba Complex). 
inliers, and underwent fragmentation in the Statherian accompanied by bimodal, syn-extensional magmatism characterized by the emplacement of predominantly, A-type leucosyenogranites and basic rocks. This process could have marked the initiation of the installation of oceanic basins that reached their climax in the Calymmian with the deposition of extensive carbonatic rocks on the marginal shelves. The Neoproterozoic history of this region started with the basic magmatism and the establishment of Stenian-Tonian basins, best represented by the deposition of the basal carbonatic units of the Itaiacoca Sequence (1030 - $900 \mathrm{Ma})$. In the upper Cryogenian/Ediacara, compared to the Mesoproterozoic sediment deposition was much reduced and constrained to basins where coarse-grained sediments predominated (Abapã, Antinha, and Iporanga). With closing of the oceanic domain between the Apiaí Terrane and the Atuba Terrane, large magmatic arcs were generated (Três Córregos, Cunhaporanga and Agudos Grandes). The collisional phase culminated around $580 \mathrm{Ma}$ with the deformation of the Ediacaran basins and the emplacement of several granitic stocks that crosscut the metasedimentary units.

\section{CONCLUSION}

Itisthenproposedthatthepresentscenarioberepresentative of the distinct tectono-sedimentary histories, reflecting a polycyclic evolution. In the Paleo to Mesoproterozoic, stable conditions prevailed, with the deposition of the majority of the sequences (Lajeado, Água Clara, Betara, Perau, Votuverava) in a passive margin context. In the Ediacaran, after the Tonian extensional phase, with deposition of the Itaiacoca Sequence, the region was transformed into an unstable active margin, with the predominance of magmatic arcs (Três Córregos, Cunhaporanga and Agudos Grandes) and restricted sedimentation (Abapã, Antinha and Iporanga Sequences). This was process related to the assembly of a collage of early Precambrian continental blocks by the consumption of the oceanic domains between them and the formation of Western Gondwana (Cordani, Brito Neves, D’Agrella, 2003; Schmitt et al., 2008; Vaughan and Pankhurst, 2008; Valladares et al., 2008; Heilbron et al., 2008; Rogers and Santosh, 2002, 2009).

\section{ACKNOWLEDGEMENTS}

We are grateful to the FAPESP for support through the grants 06/03608-6 and 05/58688-1.

\section{REFERENCES}

ALONSO, M. F.; THEUNISSEN, K. Airborne geophysics and geochemistry provide new insights in the intracontinental evolution of the Mesoproterozoic Kibaran Belt (Centrl African). Geological Magazine, v. 135, p. 203-216, 1998.

BASEI, M. A. S.; SIGA JR., O.; MACHIAVELLI, A.; MANCINI, F. Evolução Tectônica dos Terrenos entre os Cinturões Ribeira e Dom Feliciano (PR e SC). Revista Brasileira de Geociências, v. 2, p. 216-221, 1992.

BASEI, M. A. S.; SIGA JR., O.; KAULFUSS, G. A.; CORDEIRO, H.; NUTMAN, A.; SATO, K.; CURY, L. F.; PRAZERES FILHO, H. J.; PASSARELLI, C. R.; HARARA, O. M. M.; REIS NETO, J. M. Geochronology and Isotope Geology of Votuverava and Perau Mesoproterozoic Basins, Southern Ribeira Belt, Brazil. In: SOUTH AMERICAN SYMPOSIUM ON ISOTOPE GEOLOGY, 4., 2003, Salvador. Short Papers... Salvador: CBPM/IRD, 2003. v. 2, p. 501-504.

BASEI, M. A. S.; FRIMMEL, H. E.; NUTMAN, A. P.; PRECIOZZI, F. West Gondwana amalgamation based on detrital zircon ages from Neoproterozoic Ribeira and Dom Feliciano belts of South America and comparison with coeval sequences from SW Africa. In: PANKHURST, R. J.; TROUW, R. A. J.; BRITO NEVES, B. B.; WIT, M. J. (Ed.). West Gondwana: Pre-Cenozoic Correlations Across the South Atlantic Region. London: Geological Society London, Special Publication, 2008. p. 239-256.

BECKER, T.; SCHREIBER, U.; KAMPUNZU, A. B.; ARMSTRONG, R. Mesoproterozoic rocks of Namibia and their plate tectonic setting. Journal African Earth Science, v. 46, p. 112-140, 2006.

BRITO NEVES, B. B.; SÁ, J. M.; NILSON, A. A.; BOTELHO. N. F. A Tafrogênese Estateriana nos blocos Paleoproterozóicos da América do Sul e processos subseqüentes. Geonomos, v. 3, p. 1-21, 1995.

CABY, R. Terrane Assembly and Geodynamic Evolution of central-western Hoggar: a synthesis. Journal African Earth Science, v. 37, p. 133-159, 2003.

CAMPANHA, G. A. C.; GIMENEZ FILHO, A.; CAETANO, S. L. V.; PIRES, F. A.; DANTAS, A. S. L.; TEIXEIRA, A. L.; DEHIRA, L. F. Geologia e Estratigrafia da região das folhas Iporanga e Gruta do Diabo, Vale do Ribeira, São Paulo. In: CONGRESSO BRASILEIRO DE GEOLOGIA, 4., 1986. Goiânia. Anais... Goiania, 1986, v. 2, p. 1058-1073.

CAMPANHA, G. A. C. Tectônica proterozóica no alto e médio Vale do Ribeira, estados de São Paulo e Paraná. 
1991. 296 f. Tese (Doutorado) - Instituto de Geociências, Universidade de São Paulo, São Paulo, 1991.

CAMPANHA, G. A. C.; SADOWSKI, G. R. Tectonics of southern portion of the Ribeira Belt (Apiaí Domain). Precambrian Research, v. 98, p. 31-51, 1999.

CAMPANHA, G. A. C.; BASEI, M. A. S.; TASSINARI, C. C. G.; NUTMAN, A. P.; FALEIROS, F. M. Determinações Radiométricas U/Pb SHRIMP na Faixa Ribeira para a Formação Iporanga (SP). In: SIMPÓSIO 40 ANOS DE GEOCRONOLOGIA NO BRASIL, 2004. São Paulo. Boletim de Resumos ... São Paulo: IGc-USP, 2004. v. 1, p. 60.

CAMPANHA, G. A. C.; BASEI, M. A. S.; TASSINARI, C. C. G.; NUTMAN, A. P.; FALEIROS, F. M. Constraining the age of the Iporanga Formation with SHRIMP U-Pb zircon: Implications for possible Ediacaran glaciation in the Ribeira Belt, SE Brazil. Gondwana Research, v. 13, p. 117-125, 2008a.

CAMPANHA, G. A. C.; BASEI, M. A. S.; TASSINARI, C. C. G.; NUTMAN, A. P.; FALEIROS, F. M. U-Pb SHRIMP and Sm-Nd Analysis for Ribeira Belt Mesoproterozoic and Neoproterozoic Terranes. In: SOUTH AMERICAN SYMPOSIUM ON ISOTOPE GEOLOGY, 6., 2008b, Bariloche. Book of abstracts... Bariloche: INGEIS - Instituto de Geocronología y Geología Isotópica, 2008. 1 CD-ROM.

CAMPANHA, G. A. C.; BASEI, M. A. S.; FALEIROS, F. M.; TASSINARI, C. C. G.; NUTMAN, A. P.; VASCONCELOS, P. M.; DANTAS, E. L. Geocronologia do Terreno Apiaí no sul do Estado de São Paulo. In: SIMPÓSIO ANOS DE GEOCRONOLOGIA NO BRASIL, 45., 2009. São Paulo. Boletim de Resumos Expandidos... São Paulo: CPGEO-USP, 2009. v. 1, p. 220-222.

CHEMALE JUNIOR, F.; LUFT JUNIOR, J. L.; ARMSTRONG, R.; BITENCOURT, M. F. Geochronology of 1.76 to $1.50 \mathrm{Ga}$ TTD Sequences of the Hoanib Valley, Kaoko Belt, Namibia. In: SOUTH AMERICAN SYMPOSIUM ON ISOTOPE GEOLOGY, 4., 2003, Salvador. Short Papers... Salvador: CBPM/IRD, 2003. v. 2, p. 513-515.

CORDANI, U. G.; BRITO NEVES, B. B.; D’AGRELLA, M. S. From Rodinia to Gondwana: a review of the available evidence from South América. Gondwana Research, v. 6, p. $275-283,2003$.
CURY, L. F.; KAULFUSS, G. A.; SIGA JR., O.; BASEI, M. A. S., HARARA, O. M. M.; SATO, K. Idades U-Pb (zircões) de 1,75 Ga em granitóides alcalinos deformados dos núcleos Betara e Tigre: Evidências de regimes extensionais do Estateriano na Faixa Apiaí. GeologiaUSP: Série Científica, São Paulo, v. 2, p. 95-108, 2002.

DAITX, E. C. Origem e evolução de depósitos sulfetados tipo Perau (Pb-Zn_Ag), com base nas jazidas Canoas e Perau (Vale do Ribeira-PR). 1996. 453 f. Tese (Doutorado) - Instituto de Geociências, Universidade de São Paulo, São Paulo, 1996.

DE PAOLO, D. J.; LINN, A. M.; CHUBBERT, G. The continental age distribution: methods of determining mantle separation ages from $\mathrm{Sm}-\mathrm{Nd}$ isotopic data and application to the southwestern Unite States. Journal of Geophysical Research, v. 96, p. 2071-2088, 1991.

EBERT, H. D.; HASUI, Y.; QUADE, H. Aspectos da evolução estrutural do cinturão móvel costeiro da Mina do Perau, Vale do Ribeira-PR. In: CONGRESSO BRASILEIRO DE GEOLOGIA, 35., 1988. Belém. Anais... Belém, 1988. v. 1, p. 2318-2331.

FASSBINDER, E. A unidade Água Clara no contexto do Grupo Açungui: um modelo transpressivo de colisão oblíqua no Neoproterozóico paranaense. 1996. Tese (Doutorado) - Instituto de Geociências, Universidade de São Paulo, São Paulo, 1996.

FIORI, A. P. Tectônica e Estratigrafia do Grupo Açungui a Norte de Curitiba. 1990. Tese (Livre Docência) Instituto de Geociências, Universidade de São Paulo, São Paulo, 1990.

FIORI, A. P. O Grupo Açungui a norte de Curitiba. In: CONGRESSO BRASILEIRO DE GEOLOGIA, 37., 1992. São Paulo. Anais... São Paulo, 1992. V. 1, p. 279-280.

FRASCÁ, M. H. B. O.; FIGUEIREDO, M. C. H.; ALMEIDA, M. A.; COUTINHO, J. M. V. Petrografia e geoquímica da Formação Água Clara, região de Araçaíba, SP. Boletim do Instituto de Geociências: Série Científica, São Paulo, v. 21, p.73-92, 1990.

GASQUET, D.; CHEVREMONT, P.; BAUDIN, T.; CHALOT-PRAT, F.; GUERROT, C.; COCHERIE, A.; ROGER, J.; HASSENFORDER, B.; CHEILLETZ, A. Polyciclic magmatism in the Tagragra d'Akka and Kerdous-Tafeltast inliers (Western Anti-Atlas, Morocco). Journal of African Earth Science, v. 39, p. 267-275, 2004. 
GOSCOMBE, B., GRAY, D. R. The Coastal Terrane of the Kaoko Belt, Namibia: Outboard arc-terrane and tectonic significance. Precambrian Research, v. 155, p.139-158, 2007.

HANSON, R. E.; CROWLEY, J. L.; BOWRING, S. A.; RAMEZANI, J.; GOSE, W. A.; DALZIEL, I. W. D.; PANCAKE, J. A.; SEIDEL, E. K.; BLENKINSOP, T. G.; MUKWAKWAMI, J. Coeval large-scale magmatism in the Kalahari and Laurentian Cratons during Rodinia Assembly. Science, v. 304, p. 1126-1129, 2004a.

HANSON, R. E.; GOSE, W. A.; CROWLEY, J. L.; RAMEZANI, J.; BOWRING, S. A.; BULLEN, D. S.; HALL, R. P.; PANCAKE, J. A.; MUKWAKWAMI, J. Paleoproterozoic intraplate magmatism and basin development on the Kaapvaal Craton: age, paleomagnetism and geochemistry of $\sim 1.93$ to $\sim 1.87$ Ga post- Waterberg dolerites. Journal of African Earth Science, v. 107, p. 233-254, 2004 b.

HANSON, R. E.; HARMER, R. E.; BLENKINSOP, T. G.; BULLEN, D. S.; DALZIEL, I.W. D.; GOSE, W. A.; HALL, R. P.; KAMPUNZU, A. B.; KEY, R. M.; MUKWAKWAMI, J.; MUNYANYIWA, H.; PANCAKE, J. A.; SEIDEL, E. K.; WARD, S. E. Mesoproterozoic intraplate magmatism in the Kalahari Cráton: a review. Journal of African Earth Science, v. 46, p. 141-167, 2006.

HASUI, Y.; CARNEIRO, C. D. R.; COIMBRA, A. M. The Ribeira Folded Belt. Revista Brasileira de Geociências, v. 5, p. 257-266, 1975.

HASUI, Y.; CREMONINI, O. A.; BORN, H. Considerações sobre o Grupo Açungui em São Paulo e porção adjacente no Paraná. In: CONGRESSO BRASILEIRO DE GEOLOGIA, 33., 1984, Rio de Janeiro. Anais... Rio de Janeiro, 1984. v. 7, p. 3297-3306.

HEILBRON, M.; VALERIANO, C. M.; TASSINARI, C. C. G.; ALMEIDA, J.; TUPINAMBÁ, M.; SIGA JR., O.; TROUW, R. Correlation of Neoproterozoic terranes between the Ribeira Belt, SE Brazil and its African counterpart: comparative tectonic evolution and open questios. In: PANKHURST, R. J.; TROUW, R. A.; BRITO NEVES, B. B.; WIT, J. Geological Society London, Special Publication, West Gondwana: Pre-Cenozoic Correlations Across the South Atlantic Region. London: Geological Society, 2008, p. 211-238.

HOWELL, D. G. Principles of Terrane Analysis - new applications for global tectonisn. London : Chapman \& Hall, 1989a. 245 p.
HOWELL, D. G. Tectonics of Suspect Terranes - mountain building and continental growth. London: Chapman and Hall, 1989b. 221 p.

JULIANI, C.; HACKSPACHER, P.; DANTAS, E. L.; FETTER, A. H. The Mesoproterozoic volcanosedimentary Serra do Itaberaba Group of the central Ribeira Belt, São Paulo State, Brazil: implications for the age of the overlying São Roque Group. Revista Brasileira de Geociências, São Paulo, v. 30, n. 1, p. 82-86, 2000.

KAULfUSS, G. A. Geocronologia dos Núcleos de Embasamento Setuva, Betara e Tigre, Norte de Curitiba, Paraná. 2001. 115 f. Dissertação (Mestrado) - Instituto de Geociências, Universidade de São Paulo, São Paulo, 2001.

KOBER, B. Whole-grain evaporation for ${ }^{207} \mathrm{~Pb}-{ }^{206} \mathrm{~Pb}$ age investigations on single zircons using a double-filament source. Contribuition Mineralogic Petrology, v. 93, p. 482-490, 1986.

KOKONYANGI, J. W.; KAMPUNZU, A. B.; ARMSTRONG, R.; YOSHIDA, M.; OKUDAIRA, T.; ARIMA, M.; NGULUBE, D. A. The Mesoproterozoic Kibarid Belt (Katanga, SE D. R. Congo). Journal of African Earth Science, v. 46, p. 1-35, 2006.

KRONER, S.; KONOPÁSEK, J.; KRONER, A.; PASSCHIER, C. W.; POLLER, U.; WINGATE, M. T. D.; HOFMANN, K. H. U-Pb and $\mathrm{Pb}-\mathrm{Pb}$ zircon age for metamorfhic rocks in the Kaoko Belt of Northwestern Namibia: A Paleo-to Mesoproterozoic basement reworked during the Pan-African Orogeny. South African Journal of Geology, v. 107, p. 455-476, 2004.

MANIESI, V.; OLIVEIRA, M. A. F. Anfibolitos de alto magnésio da região de Rio Branco do Sul/PR In.: SIMPÓSIO DE GEOLOGIA DO SUDESTE, 5., 1997. Penedo. Anais... Penedo, 1997. v. 1, p. 97-99.

MANIESI, W.; OLIVEIRA, M. A. F. Anfibolitos com afinidades dos basaltos de fundo oceânico: regiões de Adrianópolis e Campo Largo/PR. In: CONGRESSO BRASILEIRO DE GEOLOGIA, 40., 1998, Belo Horizonte. Anais... Belo Horizonte: SBG, 1998. v. 1, p. 456.

MAPEO, R. B. M.; RAMOKATE, L. V.; ARMSTRONG, R. A.; KAMPUNZU, A. B. U-Pb zircon age of the upper Palapye Group (Botswana) and regional implications. Journal of African Earth Science, v. 40, p. 1-16, 2004. 
OLIVEIRA, M. A. F.; MELO, R. P.; NARDY, A. J. R.; ARAB, P. B.; TRINDADE, I. New U-Pb Palaeoproterozoic Zircon Age for the Cajamar Metabasite, São Roque Group, Central Ribeira Belt, southeastern Brazil. In: SOUTH AMERICAN SYMPOSIUM ON ISOTOPE GEOLOGY, 6., 2008, Bariloche. Book of abstracts... Bariloche: INGEIS - Instituto de Geocronología y Geología Isotópica, 2008. 1 CD-ROM.

OLIVER, G. J. H.; JOHNSON, S. P.; WILLIAMS, I. S.; HERD, D. A. Relict 1.4 oceanic crust in the Zambezi Valley, northern Zimbabwe: Evidence for Mesoproterozoic Supercontinental fragmentation. Geology, v. 26, n. 6, p. 571-573, 1998.

PIEKARZ, G. F. Geologia e resultados preliminares de pesquisa mineral do Núcleo Betara da Formação Perau. In: CONGRESSO BRASILEIRO DE GEOLOGIA, 33. 1984, Rio de Janeiro. Anais... Rio de Janeiro: SBG, 1984. v. 8, p. 3682-3696.

PRAZERES FILHO, H. J. Litogeoquímica, Geocronologia (U-Pb) e Geologia Isotópica dos Complexos Graníticos Cunhaporanga e Três Córregos, Estado do Paraná. 2000. 180 f. Dissertação (Mestrado)- Instituto de Geociências, Universidade de São Paulo, São Paulo, 2000.

PRAZERES FILHO, H. J.; BASEI, M. A. S.; HARARA, O. M. M.; PASSARELLI, C. R.; SIGA JR., O. Litogeoquímica, geocronologia $\mathrm{U}-\mathrm{Pb}$ e geologia isotópica $(\mathrm{Sr}-\mathrm{Nd}-\mathrm{Pb})$ das rochas graníticas dos batolitos Cunhaporanga e Três Córregos na porção sul do Cinturão Ribeira, Estado do Paraná. Geologia USP: Série Científica, São Paulo, v. 3, p. 51-70, 2003a.

PRAZERES FILHO, H. J.; BASEI, M. A. S.; PASSARELLI, C. R.; HARARA, O. M. M.; SIGA JR., O.; CURY, L. F. O Magmatismo granítico Pós-Orogênico da Faixa Apiaí: contrastes geocronológicos, petrológicos e geotectônicos. In: SIMPÓSIO DE GEOLOGIA DO SUDESTE, 8., 2003b. São Pedro-SP, Anais... São Pedro-SP, 2003b. v. 1, p. 47.

PRAZERES FILHO, H. J.; BASEI, M. A. S.; PASSARELLI, C. R.; HARARA, O. M. M.; SIGA JR., O. $\mathrm{U}-\mathrm{Pb}$ zircon ages of post-orogenetic granitic magmatism in Apiaí Folded belt (Paraná State, Southern Brazil): Petrological and geotectonic significance. In: SOUTH AMERICAN SYMPOSIUM ON ISOTOPE GEOLOGY, 4., 2003c, Salvador. Short Papers... Salvador: CBPM/ IRD, 2003. v. 2, p. 656-659.

PRAZERES FILHO, H. J. Caracterização geológica e petrogenética do Batólito Granítico Três Córregos (PR-
SP): Geoquímica Isotópica (Nd-Sr-Pb. Idades (ID-TIMS / SHRIMP) e 018 em zircão. 2005. 207 f. Tese (Doutorado) - Instituto de Geociências, Universidade de São Paulo, São Paulo, 2005.

REIS NETO, J. M. Faixa Itaiacoca: registro de uma colisão entre dois blocos continentais no neoproterozóico. 1994. 253 f. Tese (Doutorado) - Instituto de Geociências, Universidade de São Paulo, São Paulo, 1994.

RIBEIRO, L. M. A. L. Estudo Geológico - Geocronológico dos Terrenos Granito-Gnáissicos e Seqüências Metavulcanossedimentares da Região do Betara (PR). 2006. Dissertação (Mestrado) - Instituto de Geociências, Universidade de São Paulo, São Paulo, 2006.

ROGERS, J. J. W.; SANTOSH, M. Configuration of Columbia, a Mesoproterozoic Supercontinent. Gondwana Research, v. 5, n. 1, p. 5-22, 2002.

ROGERS, J. J. W.; SANTOSH, M. Tectonics and surface effects of the supercontinent Columbia. Gondwana Research, v. 15, p. 373-380, 2009.

SALAZAR, C. A.; TOMBA, C. L.; ARCHANJO, C. J.; BABINSKI, M. Anisotropia de susceptibilidade magnética e geocronologia U-Pb no batólito Itaóca, Faixa Ribeira, São Paulo. In: CONGRESSO BRASILEIRO DE GEOLOGIA, 42., 2004, Araxá. Anais... Araxá: SBG, 200. 1 CD-ROM.

SALLUN FILHO, W.; FAIRCHILD, T. R. Estudo comparativo entre estromatólitos do tipo CONOPHYTON das Faixas Ribeira e Brasília. Revista do Instituto Geológico, São Paulo, v. 26, p. 1-18, 2004.

SATO, K.; SIGA JR., O. Rapid grouth of continental crust between 2.2-1.8Ga in the South American plataform. Integrated Australian, European, North American and SW USA crustal evolution study. Gondwana Research, v. 5, p. 165-173, 2001.

SATO, K.; SIGA JR., O.; NUTMAN, A. P.; BASEI, M. A. S.; MCREATH, I.; KAULFUSS, G. A. The Atuba Complex, Southern South American Plataform: Archean components and Paleoproterozoic to Neoproterozoic tectonothermal events. Gondwana Research, v. 6, p. 251-263, 2003.

SCHMITT, R. S.; TROUW, R. A. J.; MEDEIROS, S. R.; DANTAS, E. L. Age and geotectonic setting of Late Neoproterozoic juvenile mafic gneisses and associated paragneisses from the Ribeira belt (SE Brazil) based on 
geochemistry and Sm-Nd data - Implications on Gondwana assembly. Gondwana Research, v. 13, p. 502-515, 2008.

SETH, B.; ARMSTRONG, R. A.; BUTTNER, A.; VILLA, I. M. Time Constraints for Mesoproterozoic upper anphibolite facies metamorphism in NW Namibia: a mult-Isotopic approach. Earth and Planetary Science Letters, v. 230, p. 355-378, 2005.

SETH, B.; JUNG, S.; GRUNER, B. Deciphering polymetamorphic episodes in high-grade metamorphic orogens: Constraints from $\mathrm{PbSL}, \mathrm{Sm} / \mathrm{Nd}$ and $\mathrm{Lu} / \mathrm{Hf}$ garnet dating of low- to high-grade metasedimentary rocks from the Kaoko Belt (Namibia). Lithos, v. 104, p. 131-146, 2008.

SIGA JR., O.; BASEI, M. A. S.; REIS NETO, J. M.; MACHIAVELLI, A.; HARARA, O. M. M. O Complexo Atuba: um Cinturão Paleoproterozóico intensamente retrabalhado no Neoproterozóico. Geologia USP: Série Científica, São Paulo, v. 26, p. 69-98, 1995.

SIGA JR., O.; BASEI, M. A. S.; SATO, K.; PRAZERES FILHO, H. J.; CURY, L. F.; WEBER, W.; PASSARELLI, C. R.; HARARA, O. M.; REIS NETO, J. M. U-Pb (Zircon) ages of metavolcanic rocks from the Itaiacoca Group: tectonic implications. Geologia USP: Série Científica, v. 3, p. 39-49, 2003.

SIGA JR., O.; BASEI, M. A. S.; CURY, L. F.; SATO, K.; PASSARELli, C. R. Evolução Policíclica da Faixa de Dobramentos Apiaí (PR). In: CONGRESSO BRASILEIRO DE GEOLOGIA, 2008 a Curitiba. Anais... Curitiba: SBG, 2008a. v. 1, p. 16.

SIGA JR., O.; BASEI, M. A. S.; CURY, L. F.; SATO, K.; PASSARELLI, C. R. U-Pb Geochronology of Mesoproterozoic and Neoproterozoic Sequences of Southern Apiaí Fold Belt, Paraná State- South Brazil. In: SOUTH AMERICAN SYMPOSIUM ON ISOTOPE GEOLOGY, 6., Bariloche, 2008b. Book of abstracts... Bariloche: INGEIS - Instituto de Geocronología y Geología Isotópica, 2008. 1 CD-ROM.

SIGA JR., O.; BASEI, M. A. S.; PASSARELLI, C. R.; SATO, K.; CURY, L. F.; MCREATH, I. Magmatic Records of Lower Neoproterozoic and Upper Neoproterozoic in Itaiacoca Belt (Paraná- Brazil): Zircon Ages and Lithostratigraphy Studies. Gondwana Research, v. 15, p. 197-208, 2009.

SIGA JR., O. Geocronologia da porção sul do Terreno Apiaí: implicações tectônicas. 2010. Tese (Livre-
Doscência) - Instituto de Geociências, Universidade de São Paulo, São Paulo, 2010.

SIGA JR., O.; CURY, L. F.; MCREATH, I.; RIBEIRO, L. M. A. L.; SATO, K.; BASEI, M. A. S.; PASSARELLI, C. R. Geology and Geochronology of the Betara Region in South-Southeastern Brazil: Evidence for Possible Statherian (1.80-1.75 Ga) and Calymmian (1,50-1.45 Ga) Extension Events. Gondwana Research, v. 19, p. 260-274, 2011a.

SIGA JR., O.; BASEI, M. A. S.; PASSARELLI, C. R.; SATO, K.; NUTMAN, A.; MCREATH, I., PRAZERES FILHO, H. J. Calymmian (1.50-1.45) magmatic records in Votuverava and Perau Sequences, south-southeastern Brazil: Zircon ages and Nd-Sr isotopic geochemistry. Journal of South American Earth Science, 2011b. In press.

SOARES, P. C.; STEVANATO, R.; CAMARGO, C. R. Geologia do noroeste da Faixa Itaiacoca. In: SIMPÓSIO SUL-BRASILEIRO DE GEOLOGIA, 3., 1987, Curitiba. Anais... Curitiba, 1987. v. 2, p. 245-262.

SOARES, P. C.; FIORI, A. P.; ROSTIROLlA, S. P. Organização estratigráfica e estrutural dos terrenos alóctones no Cinturão Ribeira, no Vale do Ribeira (PRSP). In: CONGRESSO BRASILEIRO DE GEOLOGIA, 40., 1998, Belo Horizonte. Anais... Belo Horizonte: SBG, 1998. v. 1, p. 41.

TASSINARI, C. C. G.; BARBOUR, A. P.; DAITX, E. C.; SATO, K. Aplicação de isótopos de $\mathrm{Pb}$ e $\mathrm{Sr}$ na determinação da natureza das mineralizações de chumbo do Vale do Ribeira - São Paulo e Paraná. In: CONGRESSO BRASILEIRO DE GEOLOGIA, 36., 1990, Natal. Anais... Natal, 1990. v. 3, p. 1254-1266.

TEGTMEYER, A.; KRÖNER, A. U-Pb zircon ages for Granitoid Gneisses in northern Namibia and their significance for Proterozoic Crustal Evolution of Southwestern Africa. Precambrian Research, v. 28, p. 311-326, 1985.

UNRUG, R. Rodinia to Gondwana: the Geodynamic Map of Gondwana Supercontinent assembly. Geological. Society of. America., v. 7, p. 1-6, 1997.

VALLADARES, C. S.; MACHADO, N.; HEILBRON, M.; DUARTE, B. P.; GAUTHIER, G. Sedimentary provenance in the central Ribeira belt based on laserablation ICPMS ${ }^{207} \mathrm{~Pb} /{ }^{206} \mathrm{~Pb}$ zircon ages. Gondwana Research, v. 13, p. 516-526, 2008. 
VAUGHAN, A. P. M.; PANKHURST, R. J. Tectonic overview of the West Gondwana margin. Gondwana Research, v. 13, p. 150-162, 2008.

WEBER, W.; SIGA JR., O.; SATO, K.; BASEI, M. A. S.; REIS NETO, J. M. U-Pb (zircon) ages of metabasic rocks of the Água Clara Formation in the Araçaíba regionSP-Brazil: preliminary data. In: SOUTH AMERICAN SYMPOSIUN ON ISOTOPES GEOLOGY, 4., 2003. Salvador. Short Papers... Salvador: CBPM/IRD, 2003. v. 2, p.706-709. 